\title{
STRUCTURAL ANALYSIS OF FOLDS SYSTEM AND RELATED MESOSTRUCTURES IN THE AREA WEST OF IRBED, JORDAN
}

\author{
${ }^{1}$ Rania B. Younes and ${ }^{\mathbf{1}}$ Abdullah A. Diabat ${ }^{*}$ \\ ${ }^{1}$ Department of Geology, Institute of Earth and Environmental Sciences, Al al-Bayt University, Jordan \\ "E-mail: adiabat@aabu.edu.jo \\ Received: 23 August 2019; accepted: 18 March 2020
}

\begin{abstract}
The study area is located in the northwestern highlands of Jordan. It is located few kilometers to the west of Irbid city and about 10 kilometers east of Jordan Valley. The aim of the study is to analyze the folds system and the related mesostructural elements. The outcropping rocks in the study area are of Late-Cretaceous age, the measured structural elements were taken from outcrop hills, road cuts and quarries. The main structural elements in the study area are folds and fractures (faults and joints). Folds are mainly anticlines, which characterized by gently dipping strata $\left(5^{\circ}-20^{\circ}\right)$, and gently plunging hinge lines $\left(3^{\circ}-18^{\circ}\right)$. Hinge lines of minor folds are mainly plunging toward $S W$ and WSW, some folds are plunging either toward NNW, SSE, NNE, NE and SSW. The interlimb angles of the folds range between $136^{\circ}-165^{\circ}$, so they are classified as gentle folds. About 2800 fracture measurements were taken from nine stations of the study area. The major trend of the fractures is NW-SE, in addition to minor trends in NNW-SSE, WNW-ESE and NE-SW. It is observed that the main trend of the fractures is normal to the hinge lines of the folds in stations 3,5 and 8, in which they parallel to the NW-SE compression direction of the Dead Sea stress system. In station -6 the main trend of the fractures is subparallel to the fold axis. Station-6 shows an over thrust fault (NNE-SSW) sub-parallel to the fold axis (NNWSSE) in which both are resulted from ESE-WNW compression of the SAS. In stations 1 and 4, the main trend of the fractures is neither parallel nor perpendicular to the fold axes, this indicates that the fractures are post-formational structures i.e. formed in later stages of the formation of the folds. Some folds were truncated by major faults which indicate that the folding phase was followed by faulting phase. The study area has been affected by both stress fields in the region, these are the SAS since the Turonian to Oligocene, and the Dead Sea stress since Middle Miocene to Recent.
\end{abstract}

Keywords: Folds; Faults; Mesostructures; Paleostress; Jordan 


\section{INTRODUCTION}

The structural pattern of Jordan was affected by the opening of the Red Sea and the Gulf of Aden, and the left movement along the Dead Sea transform fault (Fig.1). The regional tectonics of the continental part of Arabian Plate (including Jordan) has been studied throughout macrostructures by many authors, but few analyses of the regional tectonics based on mesostructures (Diabat et al., 2004; Diabat, 2015). The Fold structures in Jordan were explained by many researchers. Examples of structures related to the Syrian Arc Fold Belt (SAF) are Ajlun Dome, Koura Basin, Amman- Hallabat structure (Abed, 2000), fold structures found in Jordan between the Jordan Valley and the basalt Plateau (Atallah and Mikbel, 1992); they are the Halawa-Al Husun, Ibbin-Hausha and Bal'ama-Al Mafraq fold belts (Fig. 2), and also in south Jordan. The major trend of these fold axes is NE to ENE. These folds were formed by SE and SSE compressive stresses, due to the northward movement of the Arabian plate. In northern Jordan, the area east of the Jordan Valley was studied by Mikbel and Zacher (1981\&1986). Through the fieldwork, they explained many compressional fold belts formed as a result of SE-NW compressional stresses acting since the late Cretaceous. Fold are also found in southern Jordan; Petra - Shaubak and Diylagha- Ail structures are two examples of them (Abu Taimeh, 1988; Atallah, 1992) (Fig. 2).

Mesostructures are considered to be accurate indicators of the paleostress and strain orientation (Angelier,1979,1989; Delvaux et al.,1995). Eyal and Reches (1983) presented a study based on mesostructural analysis and found two major stress systems in the Levant area, they are the Syrian Arc Stress System (SAS), trending ESE and responsible for the formation of the Syrian Arc Fold Belt (SAF). The second system is the Dead Sea Stress System (DSS) trending SSE and responsible for the horizontal displacement along the Dead Sea Transform. The study area is located in the northwestern highlands of Jordan according to Bender (1974). It is located few kilometers to the west of Irbid city and few kilometers east of Jordan valley. It includes Zahar, Kufr Yuba, Bayt Yafa, Dayr Yousef and Samue towns, where Late Cretaceous rocks are well exposed in many quarries and outcrop hills. The study area covers about $70 \mathrm{~km}^{2}$ which is bounded by the coordinates: $32^{\circ} 30^{\prime} 00^{\prime \prime}-32^{\circ} 35^{\prime} 00^{\prime \prime} \mathrm{N}$ and $35^{\circ} 45^{\prime} 00^{\prime \prime}$ - $35^{\circ} 50^{\prime} 00^{\prime \prime}$ E (Fig. 3). In general, the area is hilly and cut by many Wadis and their tributaries. A digital elevation map of the study area is produced (Fig. 3). The map shows the elevation of the study area ranges from $300 \mathrm{~m}$ above sea level (a.s.1.) in the northwestern parts to $750 \mathrm{~m}$ (a.s.l) in the southern parts. The aims of this study are to analyze the fold systems and the related mesostructural elements (e.g., faults, joints), in addition, to deduce the stress fields in the study area. 


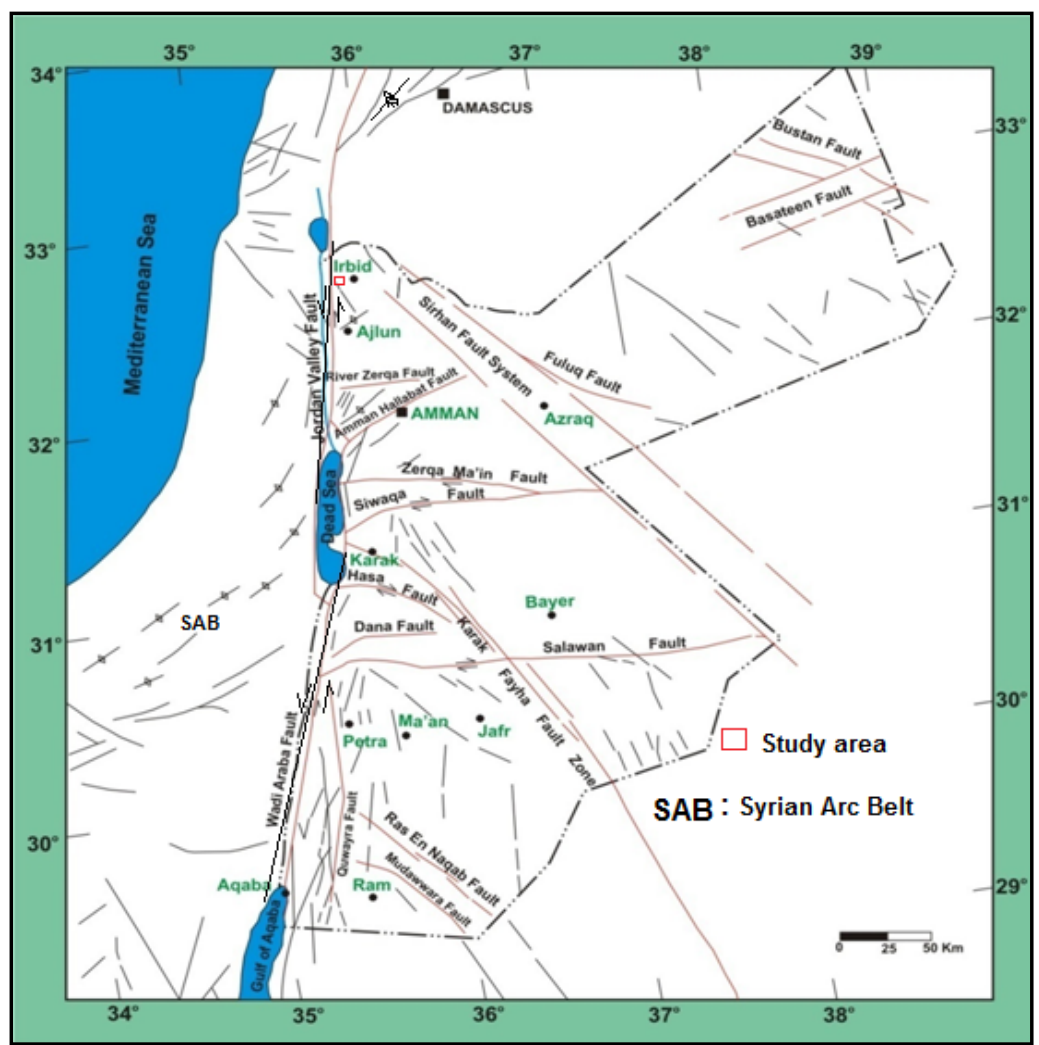

Fig. 1. The structural pattern of Jordan showing the study area (after Diabat and Masri, 2005)

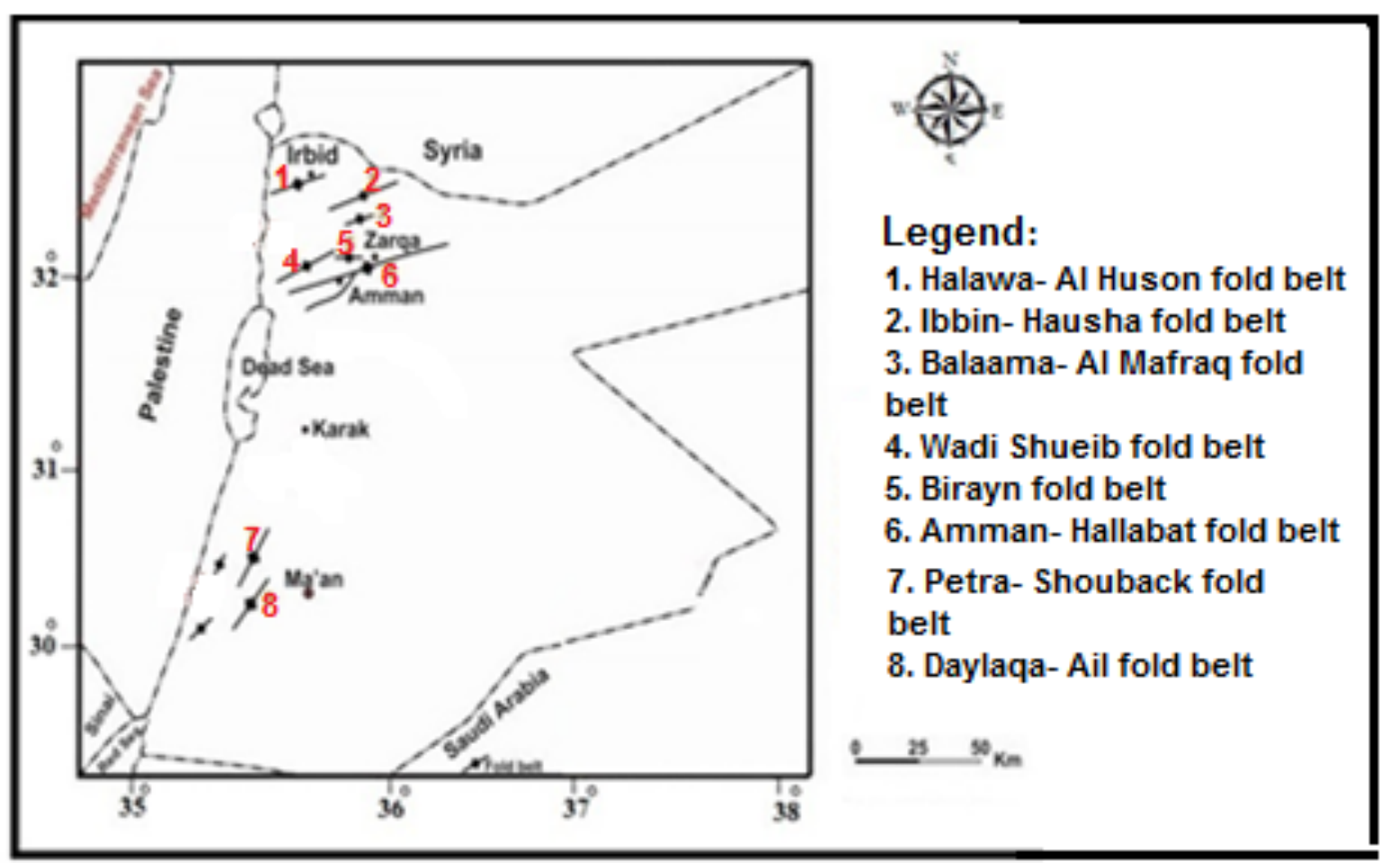

Fig. 2: Fold belts in Jordan (Modified after Atallah, 1992) 


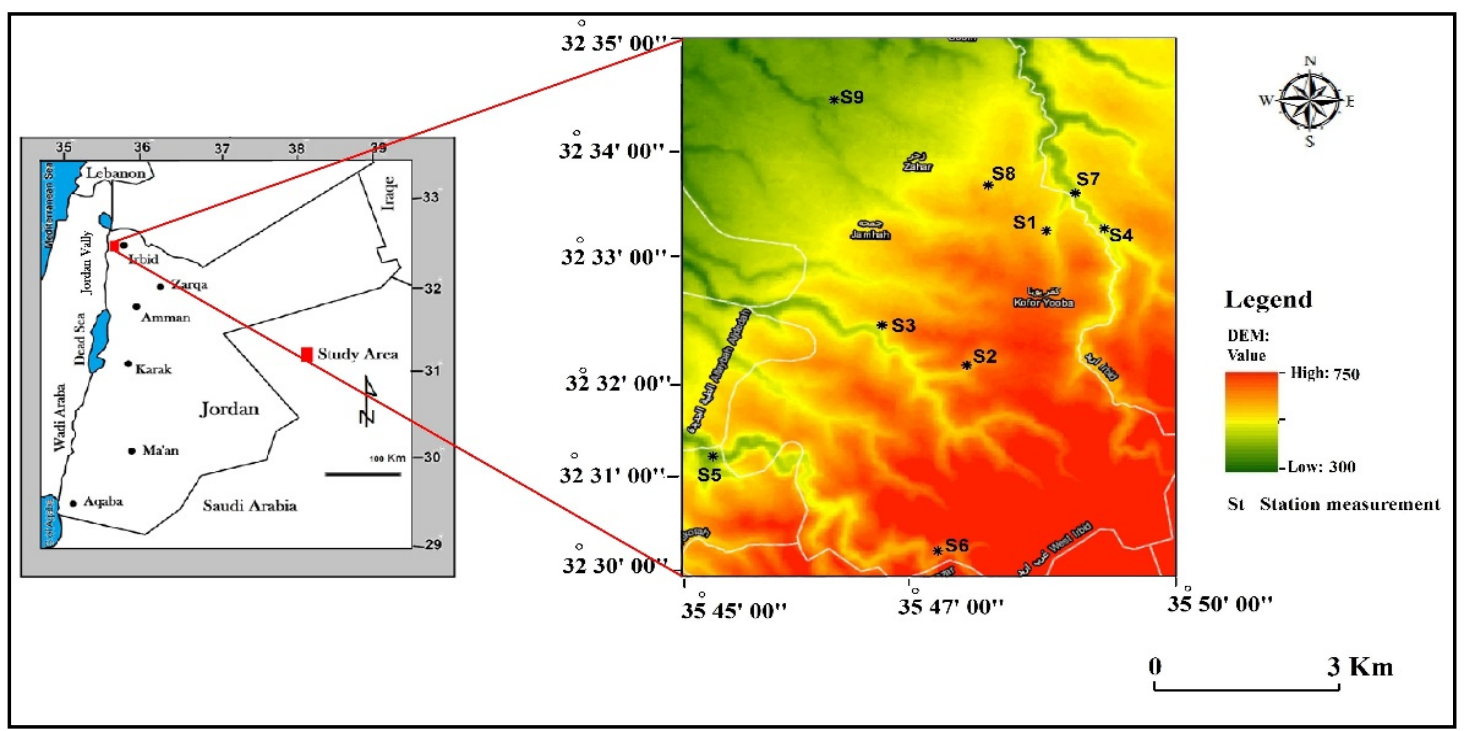

Fig. 3. Location and elevation maps of the study area with the locations of station measurements

\section{GEOLOGICAL SETTING}

\section{Stratigraphy}

The major rock outcrops in the study area are of Late Cretaceous. Ajlun and Belqa Groups cover the study area. Ajlun Group includes WadiAs Sir Formation. Belqa Group includes Ghudran, Amman, and Muwaqqer (Figs. 4 and 5).

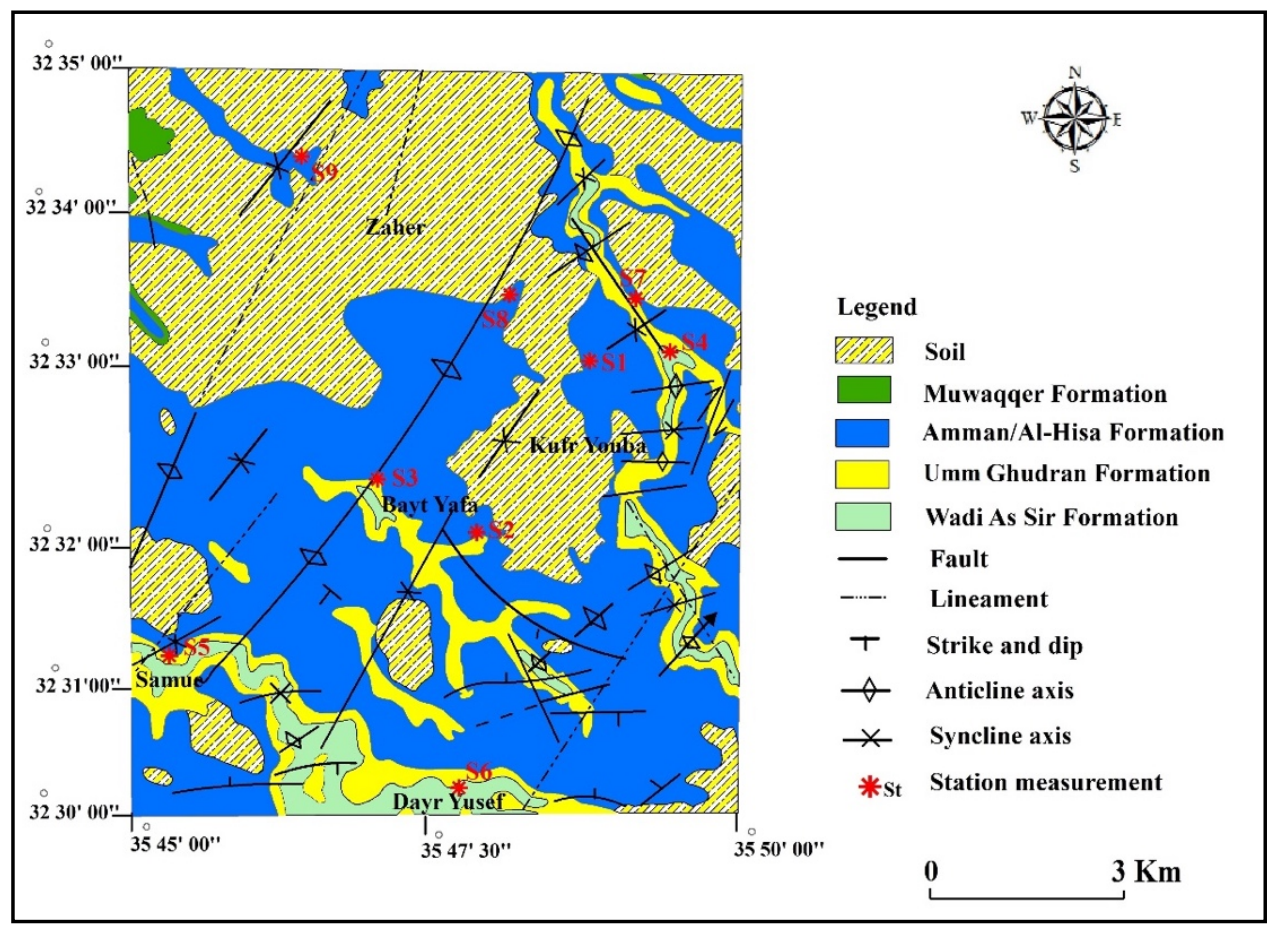

Fig. 4. Geological map shows the locations of station measurements in the study area (after, Moh'd, 2000) 
Throughout most of Jordan, the Wadi As Sir Formation (Turonian) represents the topmost part of the Ajlun Group and is disconformably overlain by the white chalk of the basal Belqa Group (Powell, 1989). The Wadi As Sir Formation is a very distinctive, white to very light gray limestone, which weathers brown, microcrystalline and thinly bedded with very thin marl parting, fractured, medium hard concretionary, become chalky at the top and base, it can easily be defined from the overlying marl of the base of Ghudran Formation. Wadi As Sir Formation crops out only in the most southern part of the study area (Fig. 4).

Ghudran Formation represents the lowermost part of the Belqa Group; it consists of about $15 \mathrm{~m}$ chalky limestone, and $15 \mathrm{~m}$ of limestone and chalky limestone in the upper half. The formation is cropping out in the western and southern parts of the study area (Fig. 4). Amman Formation consists of medium to thin bedded, locally thick chert, silicified limestone, limestone, and phosphatic chert layers at the top. The base of Amman Formation (Santonian) lies conformably on top of the Wadi Umm Ghudran Formation, it crops out in many localities in the area and is usually consistent in lithology throughout the area of outcrop. Thin chert beds, phosphatic chert and a few thin phosphatic beds characterize the uppermost part. A characteristic feature of the Amman formation is the undulating structure of its beds. It is widely spreading in the study area (Fig. 4).

\section{Tectonic Setting}

There are two main trends of the fold belts in Jordan; the first one is NNE-SSW and the other is ENE-WSW (Atallah, 1992). The first fold trend could be formed as a result of SE-NW compression, responsible for the formation of the Dead Sea Transform (DST); this trend coincides with the Riedel model of fractures associated with major strike-slip fault system. Whereas the second trend is most probably part of the SAS (Sahawneh and Atallah, 2002). The Syrian Arc forms a conspicuous S-shaped fold-thrust belt (Fig.1). The tectonic evolution of the Syrian Arc fold-thrust belt had been markedly influenced by the opening and closing of the Neo-Tethyan Ocean around the margins of the Afro-Arabian plate. The opening of the Neo-Tethys, in the Eastern Mediterranean region, started in the Late Permian (Garfunkel and Derin, 1984; De Ruiter et al., 1994; Ricou, 1995; Robertson et al., 1996 and Sharland et al.,2001). The study area lies within the Highlands east of the northern segment of the Dead Sea Transform (DST). The northern segment of the DST is the Jordan Valley active strikeslip fault (Fig. 1). It extends from the northwestern of the Dead Sea to the southeastern of lake Tiberias with a general N-S trend (Diabat, et al., 2015). The Jordan Valley, between the sea of Galilee to the north and the Dead Sea to the south, is a long and narrow depression that is part of the Syrian-African Rift system (Garfunkel and Derin, 1984). 


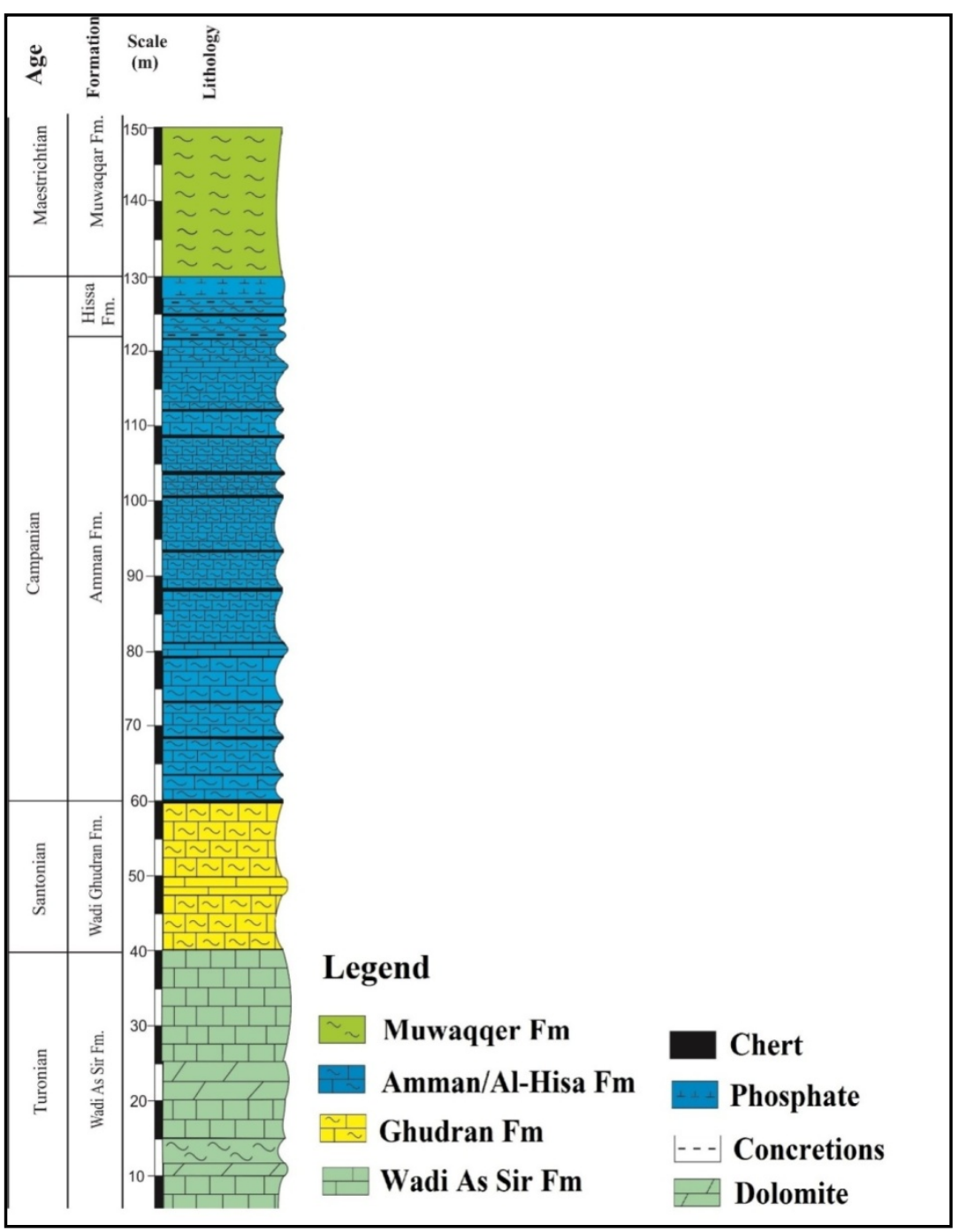

Fig. 5. General lithostratigraphic units of the study area

This system extends from southern Africa through east Africa and the Red Sea to southern Turkey (Freund et al., 1970; Garfunkel, 1981; Horowitz, 2001). The sinistral DST is $1100 \mathrm{Km}$ long and connects the Gulf of Aqaba-Red Sea spreading system to the convergence zone in the Taurus-Zagros Mountain. The DST is the major tectonic feature controlling the geological and geomorphological evolution of the region since the Miocene (Garfunkel, 1981). The Dead Sea Transform (DST) fault is the most prominent structure in Jordan that resulted from the northward faster movement of the Arabian Plate relative to that of the African Plate, in relation to the Red Sea opening (Quennel,1958; and Grafunkel, 1981). The Dead Sea Transform fault is left lateral, comprised of a zone of en echelon strike-slip faults. Motion on the Dead Sea Transform initiated in the Miocene and has a cumulative lateral displacement of about 107 km (e.g., Quennell,1958; Freund et al.,1970 and Garfunkel,1981). The displacement along the Dead Sea has been the major source for the stress stored in the rocks along with the transform, resulting in internal deformation of plates adjacent to it (Eyal, 
1996). The Dead Sea Transform is the major tectonic feature controlling the stratigraphic and structural evolution region since the Miocene (Zain El deen et al.,2002).

\section{METHODOLOGY}

This study concentrated on detailed field measurements of the various structural elements such as folds and fractures (mainly joints). The data were taken from nine main measurement stations; S1, S2, S3,.... and S9 (Fig. 4). Each measurement station consists of quarries, road cuts or clear outcrops. These stations are selected due to easy reaching and the abundant data which are found in parts of the study area. Orientations of 2800 meso-scale fractures (joints and faults), in addition to many bedding planes to determine the fold hinge lines in each measurement station that measured in the field. Most of the fractures are considered as joints which lack any shear indicators on their surfaces. The fractures that have striations on their surfaces (faults) were used to compute the stress tensors using the TENSOR program (Delvaux, 1993; Sperner et al., 2003). The stereographic projection and rose diagrams are used in data analyzing, whereas the produced lineaments map and DEM (Fig. 3) used the following techniques and software:

- Google earth for projection coordinates of the study area to overlay with lineament map.

- Using ERDAS 2016, PciGeomatics 2016, and Rockworks16.exe to produce lineament map.

- Using Coral draw x5 2010 to draw vertical and horizontal geological cross-sections.

\section{RESULTS}

The study area has been sub-divided into nine main stations, located west of Irbid city and named S1, S2, ., and S9 with new described folds (Fig. 6) and Table (1). A NW-SE crosssection (A-B) was drawn to show the general view of folds in the study area (Fig. 7).

\section{Station 1}

The data of this station were collected from Amman Silicified limestone and Al-Hisa Phosphorite Formation, which is about $4 \mathrm{~km}$ west of Irbid city (Fig. 5). Ten bedding planes were measured in the field and represented as stereographic projection and determined hinge line, axial plane and profile plane (The best fit great circle of poles) (Fig. 8 a). It shows a slightly plunging symmetric anticline towards NNW $\left(17^{\circ} / 351^{\circ}\right)$. The interlimb angle is $163^{\circ}$ showing a gentle anticline according to (Van der Pluijm et al., 2004). Three hundred fracture measurements mainly joints were measured in this station. A NW-SE main trend is observed in the rose diagram (Fig. 8 b). Sigmoidal en echelon arrangement of fractures were observed which indicate a dextral shear zone-oriented NNW-SSE (Fig. 9a). The Listric normal fault was also observed cutting Amman Formation striking NE-SW and dipping SE (Fig.9b). It 
also observed a fault zone trending ENE-WSW with a dextral sense make tilting of the strata in which the strata at the southern side of the fault have steeper dip than on the northern side (Fig. 9 c).

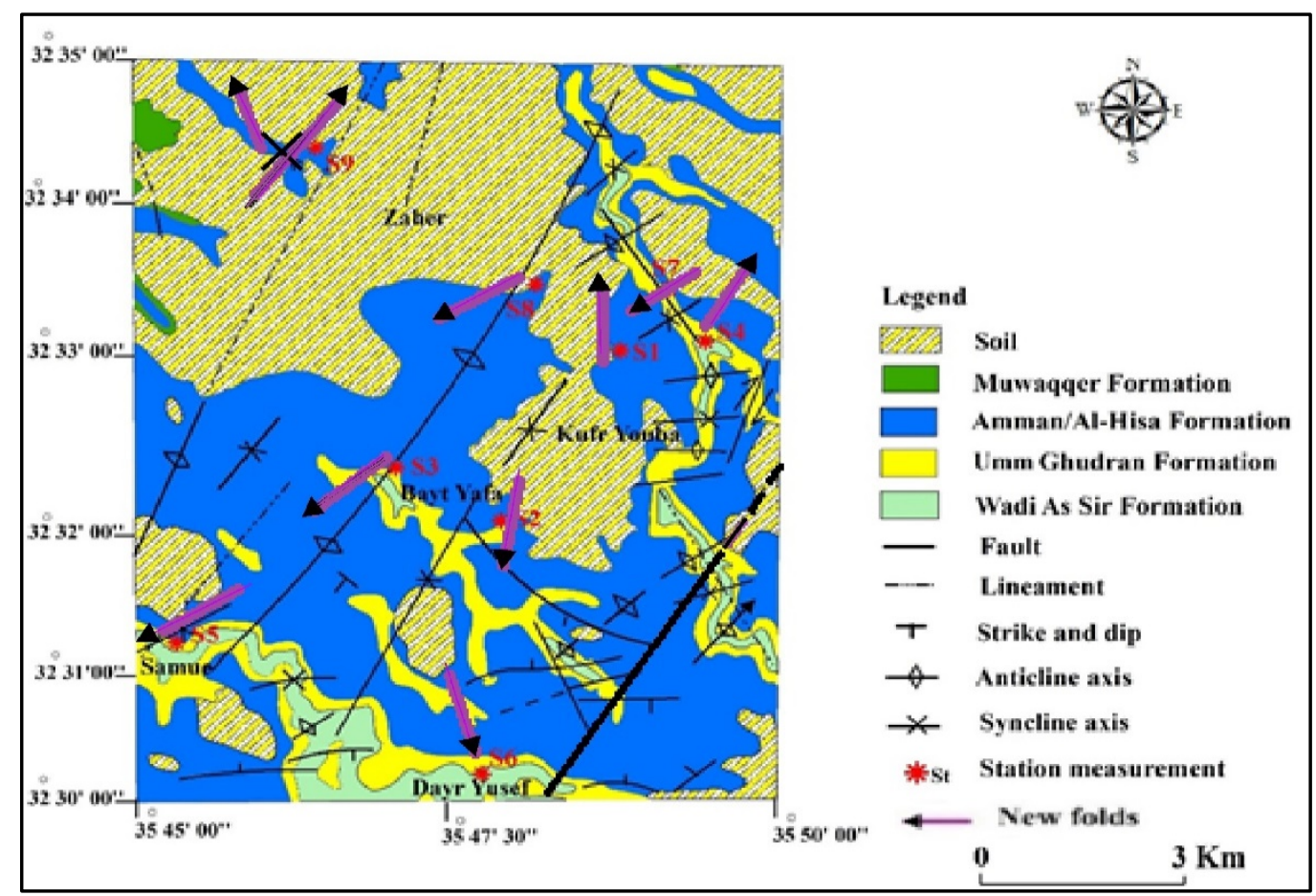

Fig. 6. Geological map shows the location of station measurements and the new described folds in the study area

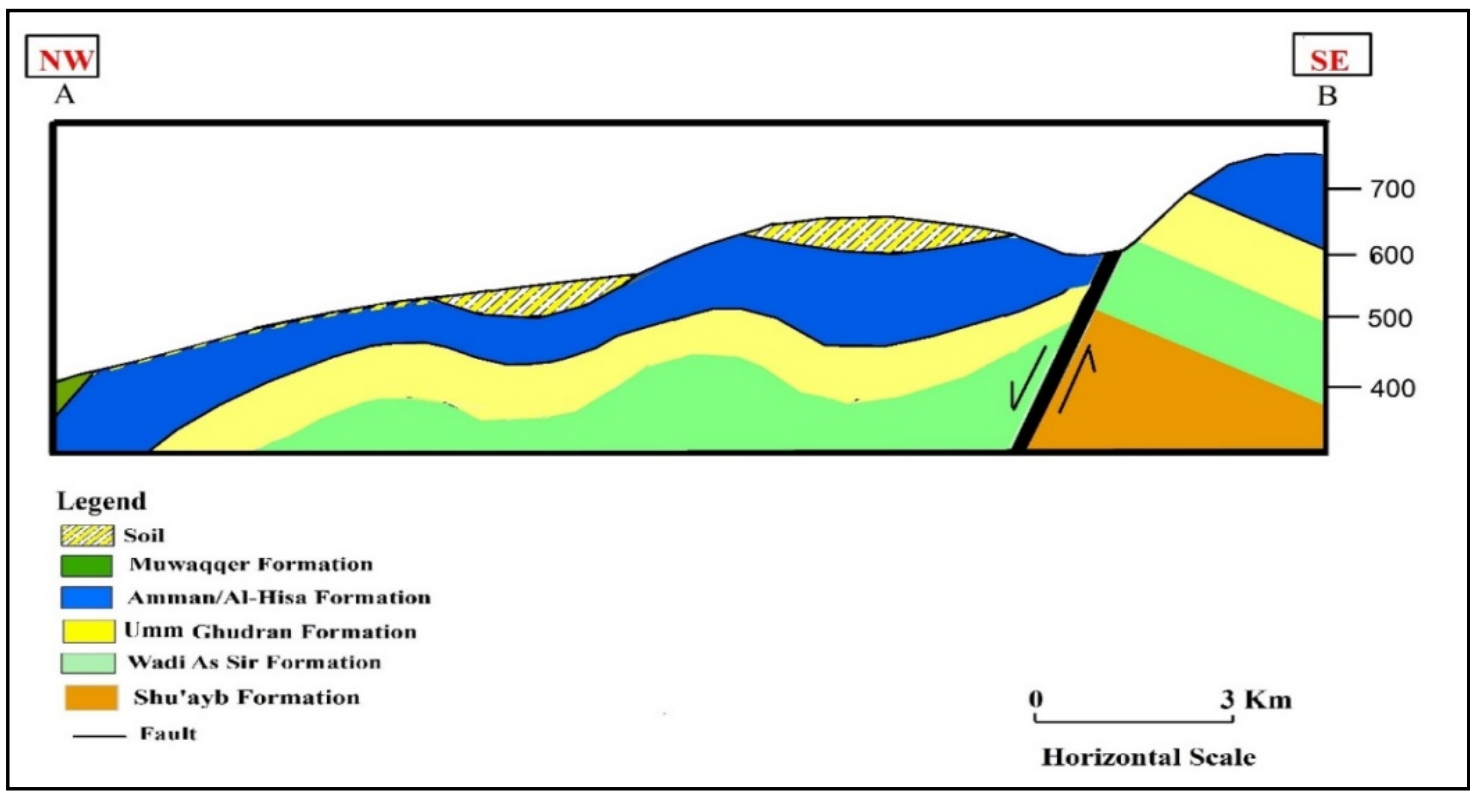

Fig. 7. A NW-SE (A-B) geological cross-section of the study area 


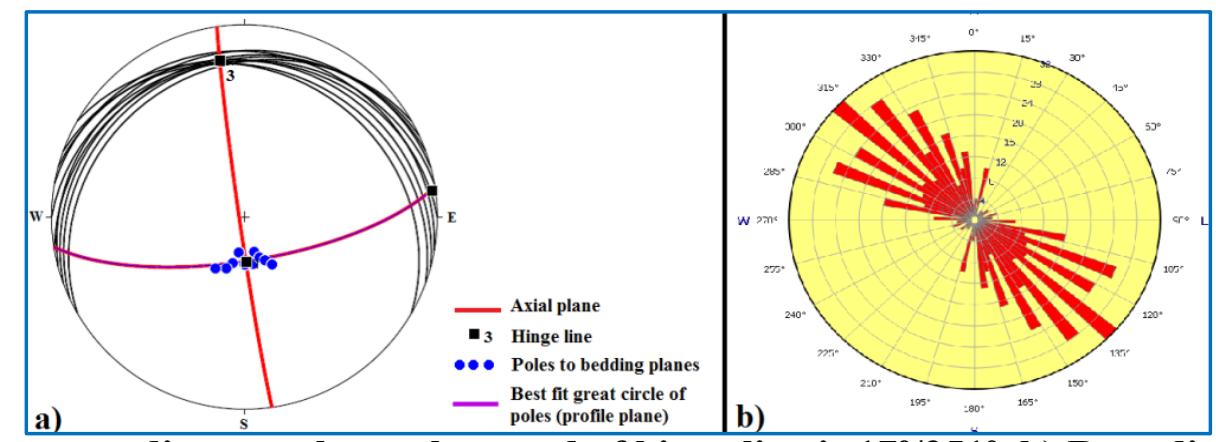

Fig. 8. a) Stereonet diagram shows the trend of hinge line is $17^{\circ} / 351^{\circ}$, b) Rose diagram of 300 joints in station 1

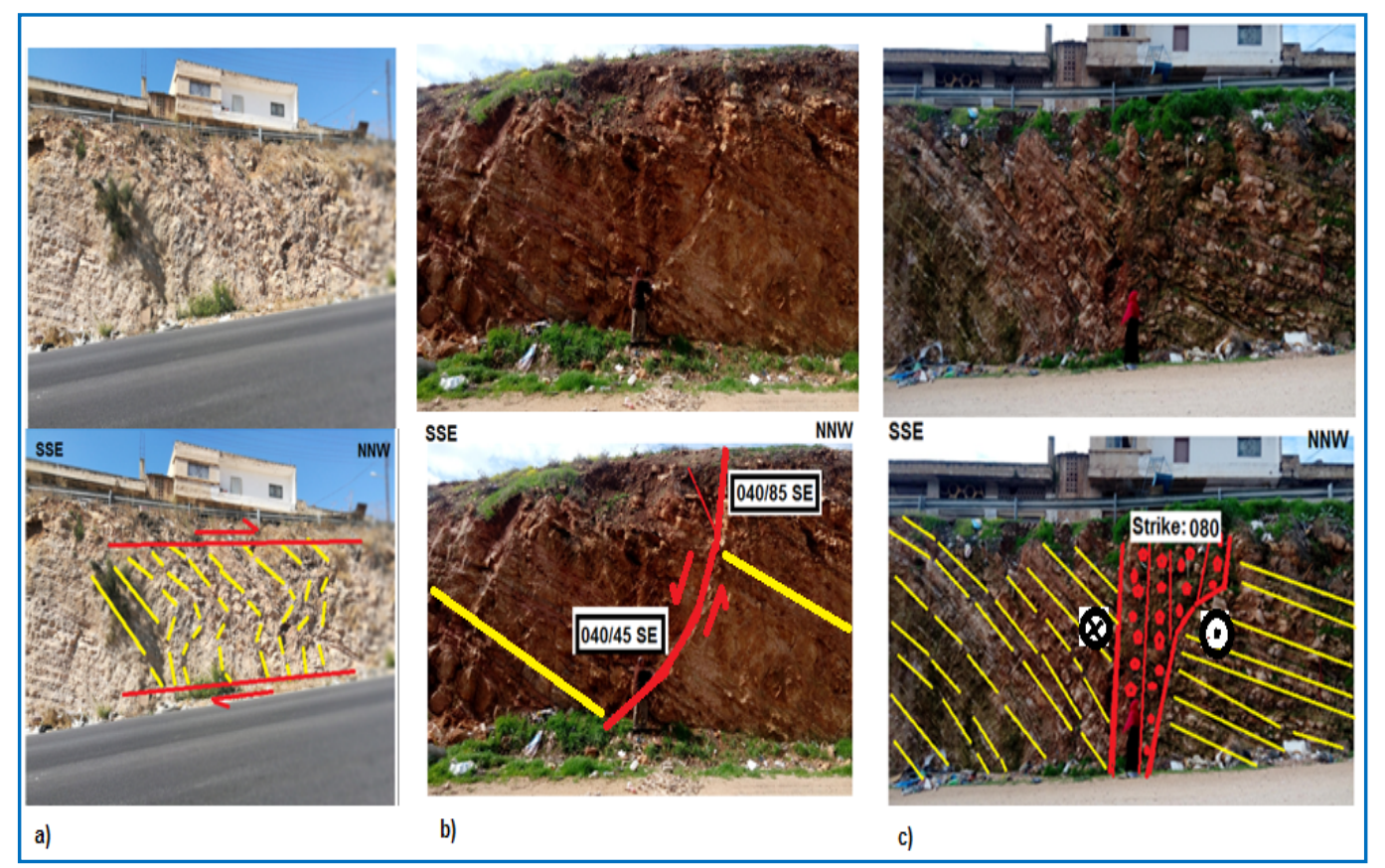

Fig. 9. a) Kinematic indicators of a) Shear zone, b) Listric normal fault, and c) Fault zone-oriented ENE- WSW (dot shows block toward the observer and cross is away from the observer)

\section{Station 2}

The data of this station were collected from Wadi Umm Ghudran Formation, which is about 6 km west of Irbid (Fig. 5). Eighteen bedding planes were measured in the field and represented as stereographic projection, which determined hinge line, axial plane and profile plane (Fig. 10). It shows symmetric anticline with a slightly plunging hinge line towards SSW $\left(10^{\circ} / 189^{\circ}\right)$. The interlimb angle is $161^{\circ}$ showing a gentle anticline (Fig. 11). It also observed slightly plunging small anticline and syncline affected by faulting (Fig. 12). 


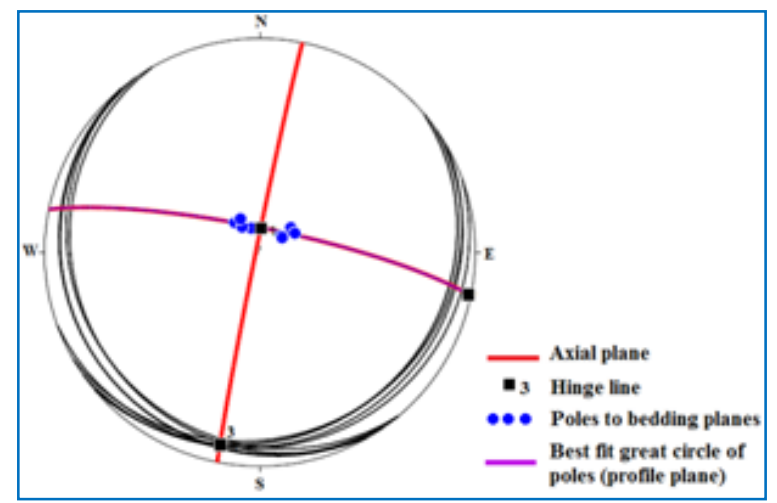

Fig. 10. Stereonet diagram shows the trend of hinge line $10^{\circ} / 189$

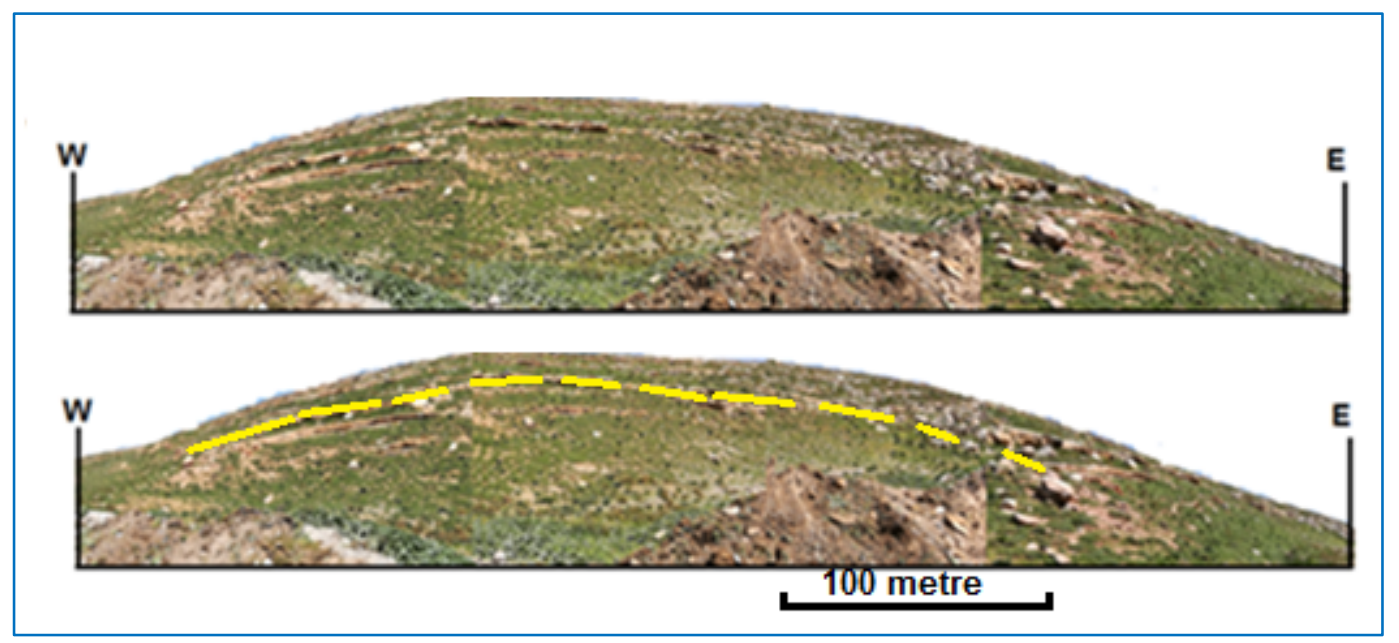

Fig. 11. Anticline in panorama view in station2

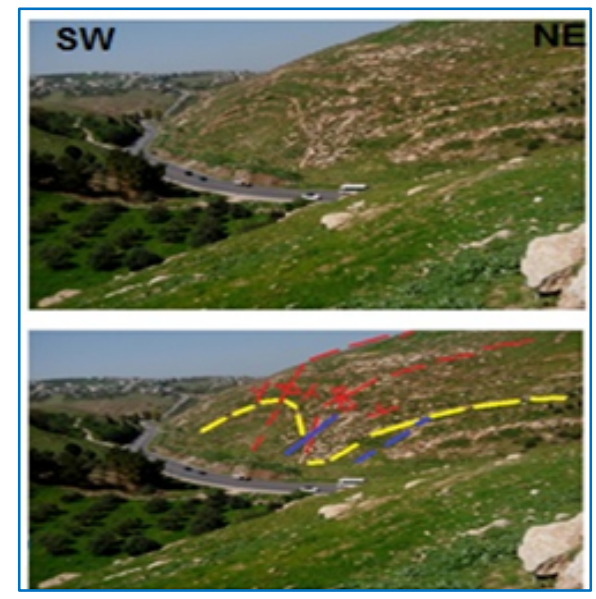

Fig. 12. Faulted anticline and syncline in station 2

\section{Station 3}

The data were collected from Wadi Umm Ghudran Formation, which is about $7 \mathrm{~km}$ west of Irbid city (Fig. 4). Twenty bedding planes were measured in the field and represented as stereographic projection which determined hinge line, axial plane and profile plane (Fig. 13a). 
It shows symmetric anticline with slightly plunging hinge line towards WSW $\left(03^{\circ} / 244^{\circ}\right)$. The interlimb angle is $150^{\circ}$ showing a gentle anticline. Six hundred fracture measurements mainly joints were collected from this station. A NW-SE main trend is observed in the rose diagram (Fig. 13b). Horizontal slickenlines with a dextral sense of movement were measured on some fault planes oriented WNW- ESE (Fig. 14a \& b). Another slickensided sinistral fault plane which oriented NW-SE ( i.e dip direction/ dip 230/70) was observed (Fig.14c \& d). A stress tensor was produced using the Win TENSOR -Program show that a strike-slip regime with NNW- SSE compression and ENE -WSW tension (Fig.14 a). This station also shows vertical slickenlines on a fault plane oriented NW-SE (Fig.14 e). This fault- slip data resulted in stress tensor characterized by NE- SW tension (Fig.14e). Brecciated fault zone oriented 215/ 70 also observed (Fig.14f).

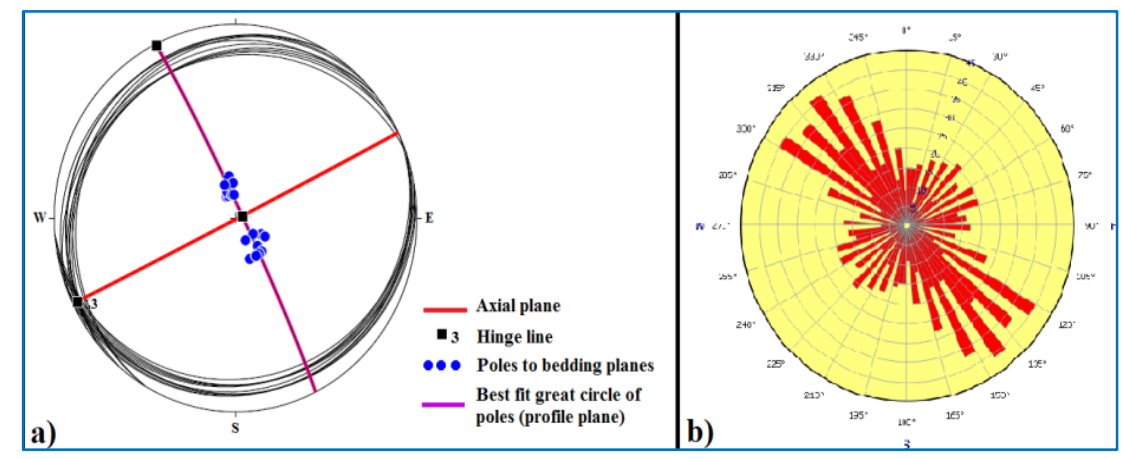

Fig. 13. a) Stereonet diagram shows the trend of hinge line $03^{\circ} / 244^{\circ}$, b) Rose diagram of 600 joints in station 3

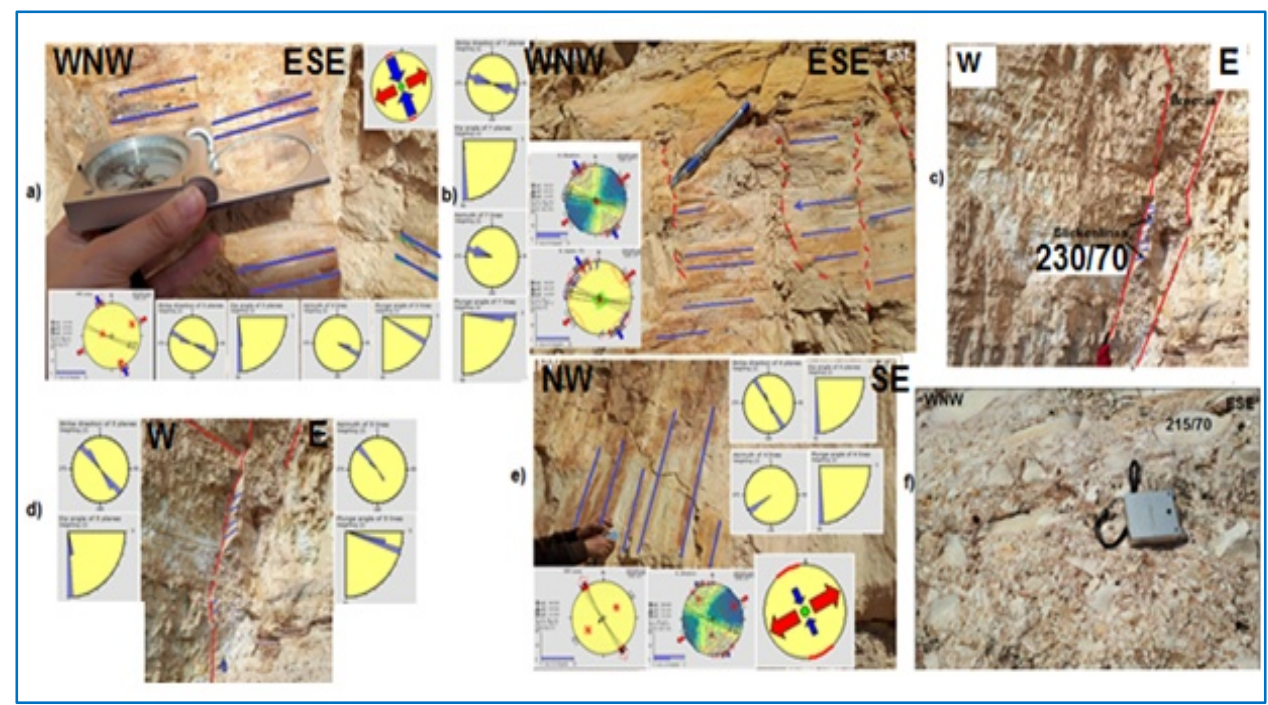

Fig. 14. Horizontal and vertical slickenlines in addition to fault breccias which were observed in Wadi as Sir Formation. It also shows rose diagrams represent strike, dip of fault planes, azimuth and plunge of the slickenlines and the representative tensors 


\section{Station 4}

The data of this station were collected from Wadi As Sir Formation, which is about $3 \mathrm{~km}$ west of Irbid city (Fig. 4). Fourteen bedding planes were measured in the field and represented thru stereographic projection and determined hinge line, axial plane and profile plane (Fig. $15 \mathrm{a}$ ). It shows slightly plunging symmetric anticline towards NNE $\left(04^{\circ} / 022^{\circ}\right)$. The interlimb angle is $136^{\circ}$ showing a gentle anticline. A fault zone was observed with a sinistral sense oriented NNW-SSE (Fig. 16). This indicated by the tilting of strata particularly at the eastern side of the fault which has dragging and steeper dip than the left side.
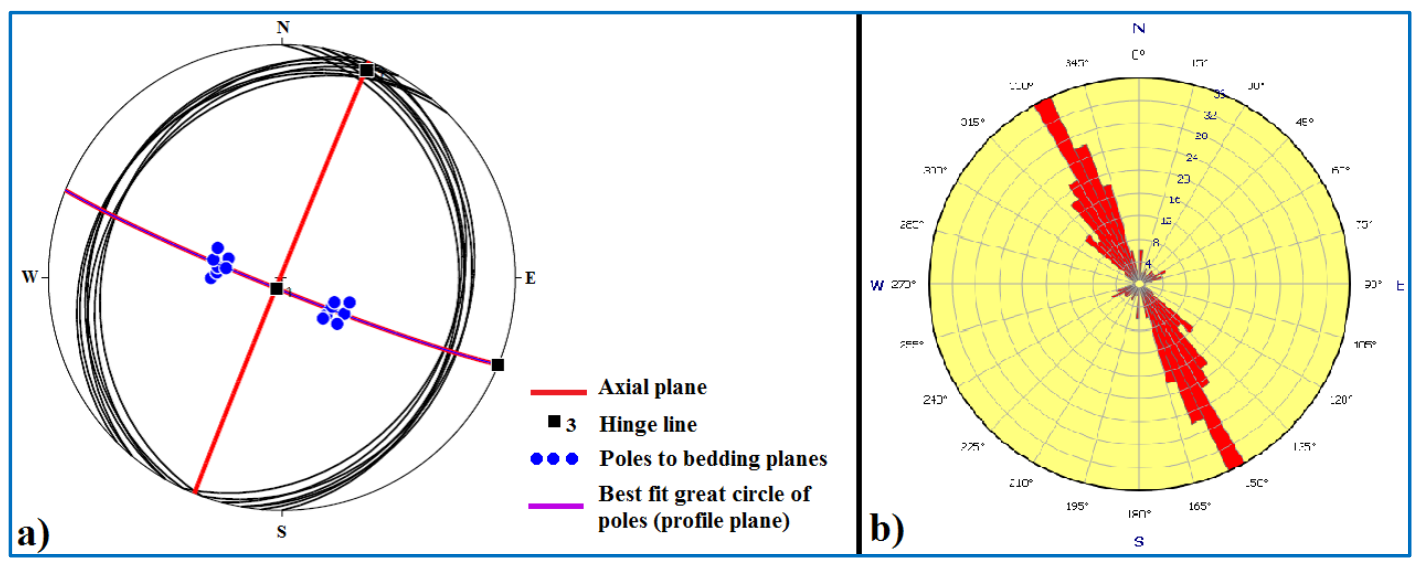

Fig. 15. a) Stereonet diagram shows the trend of hinge line is $04^{\circ} / 0^{\circ}$ b) Rose diagram of 200 joints in station 4

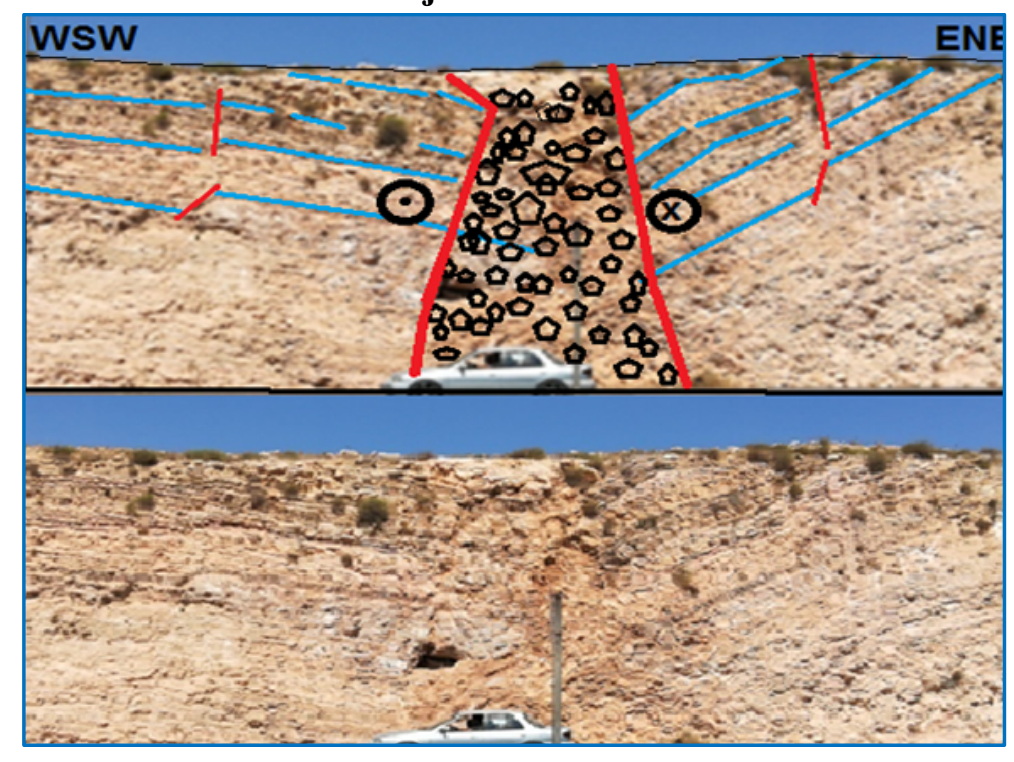

Fig. 16. Sinistral strike - slip fault zone

\section{Station 5}

The data of this station were collected from Wadi Umm Ghudran Formation, which is about $10 \mathrm{~km}$ west of Irbid (Fig. 4). Fourteen bedding planes were measured in the field and represented thru stereographic projection and determined hinge line, axial plane and profile plane (Fig. 17a). It shows slightly plunging symmetric anticline towards SW $\left(03^{\circ} / 223^{\circ}\right)$. The 
interlimb angle is $148^{\circ}$ showing a gentle anticline. Eight hundred fracture measurements mainly joints were collected from this station. A NW-SE main trend is observed in the rose diagram (Fig. 17 b).
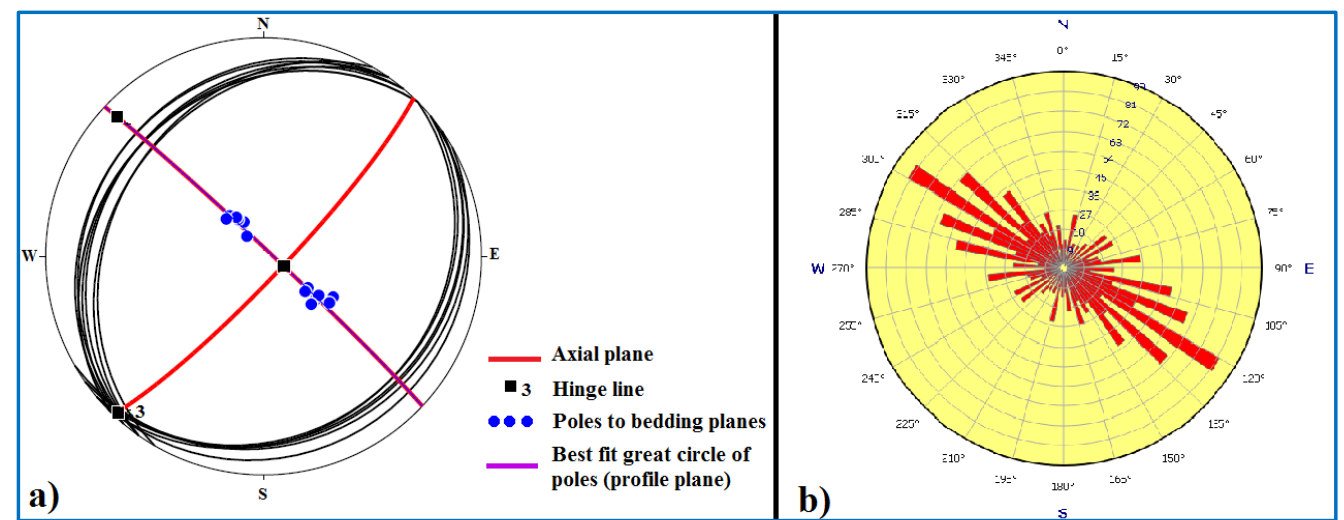

Fig. 17. a) Stereonet diagram shows the trend of hinge line is $03^{\circ} / 223^{\circ}$ b) Rose diagram

\section{Station 6} of 800 joints in station 5

The data of this station were collected from Wadi As Sir limestone Formation, which is about $8 \mathrm{~km}$ southwest of Irbid city (Fig. 4). Fourteen bedding planes were measured in the field and represented as stereographic projection and determined hinge line, axial plane and profile plane (Fig. 18 a). Figure (19) shows the eastern limb of the anticline. It shows symmetric slightly plunging anticline towards $\operatorname{SSE}\left(11^{\circ} / 176^{\circ}\right)$ (Fig. 18 a). The interlimb angle is $142^{\circ}$ showing a gentle anticline. Six hundred fracture measurements mainly joints were collected from this station. A N-S main trend is observed in the rose diagram and two minor trends oriented NNW and NNE (Fig. 18b). It is also observed horizontal slickenlines indicating a strike- slip movement in Wadi As Sir Formation and an overthrust fault in Umm Ghudran Formation (Fig.20). This indicates that a permutation of principal stress axes i.e $\circ 2$ and $\circ 3$ was locally changed.

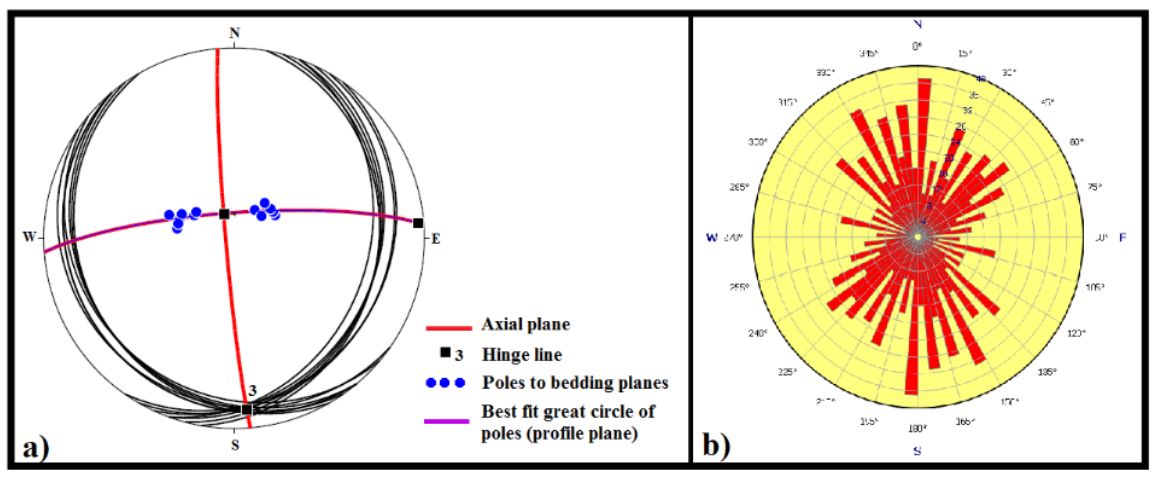

Fig. 18. a) Stereonet diagram shows the trend of hinge line is $11^{\circ} / 016^{\circ}$ b) Rose diagram of 600 joints in station 6 


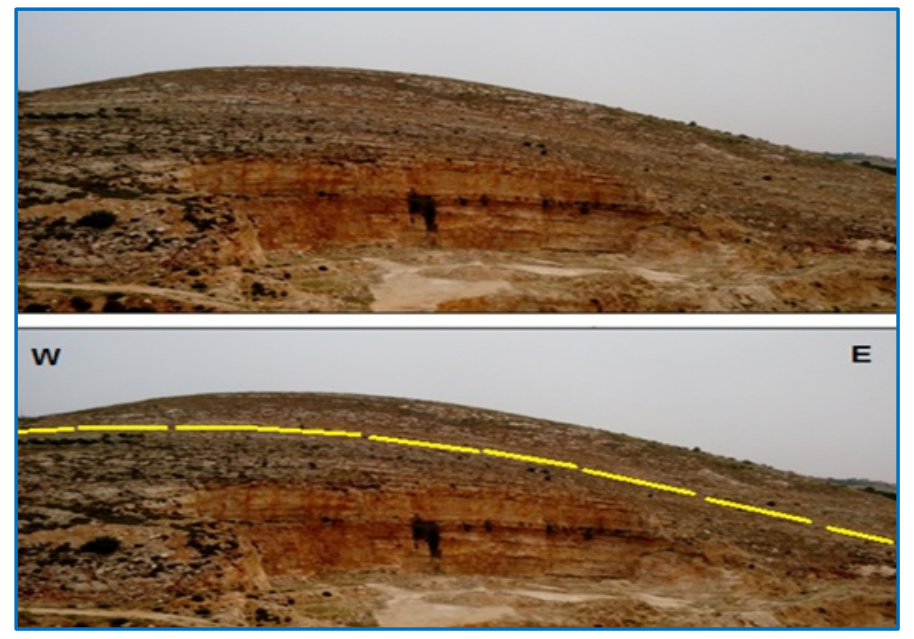

Fig. 19. The eastern limb of the anticline in station 6

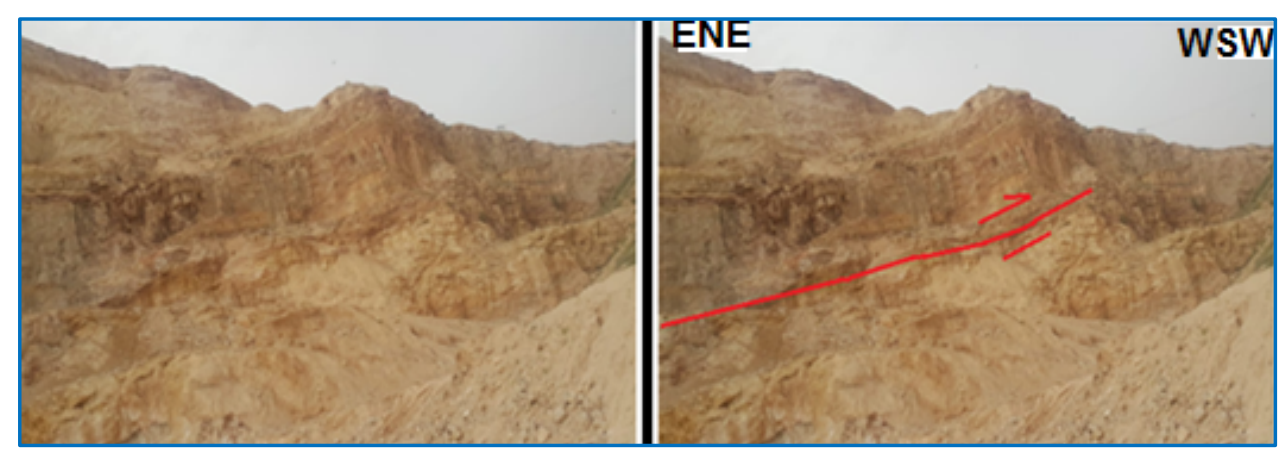

Fig. 20. Overthrust fault in station 6

\section{Station7}

The data of this station were collected from Wadi Umm Ghudran Formation, which is about 4 km west of Irbid city (Fig. 4). About ten bedding planes were measured in the field and represented as stereographic projection and determined hinge line, axial plane and profile plane. It shows symmetric slightly plunging anticline towards WSW $\left(05^{\circ} / 258^{\circ}\right)$ (Fig. 21). The interlimb angle is $148^{\circ}$ showing a gentle anticline.

\section{Station 8}

The data of this station were collected from Amman Silicified limestone and Al-Hisa Phosphorite Formation, which is about $5 \mathrm{~km}$ from Irbid city (Fig. 4). Twenty-three bedding planes were measured in the field and represented as stereographic projection and determined hinge line, axial plane and profile plane (Fig. 22a). It shows slightly plunging symmetric anticline towards WSW $\left(05^{\circ} / 236^{\circ}\right)$. The interlimb angle is $165^{\circ}$ showing a gentle anticline.

About three hundred fracture measurements mainly joints were collected from this station. A NW-SE main trend is observed in the rose diagram (Fig. 22b). Listric normal fault was observed in this station (Fig. 23). 


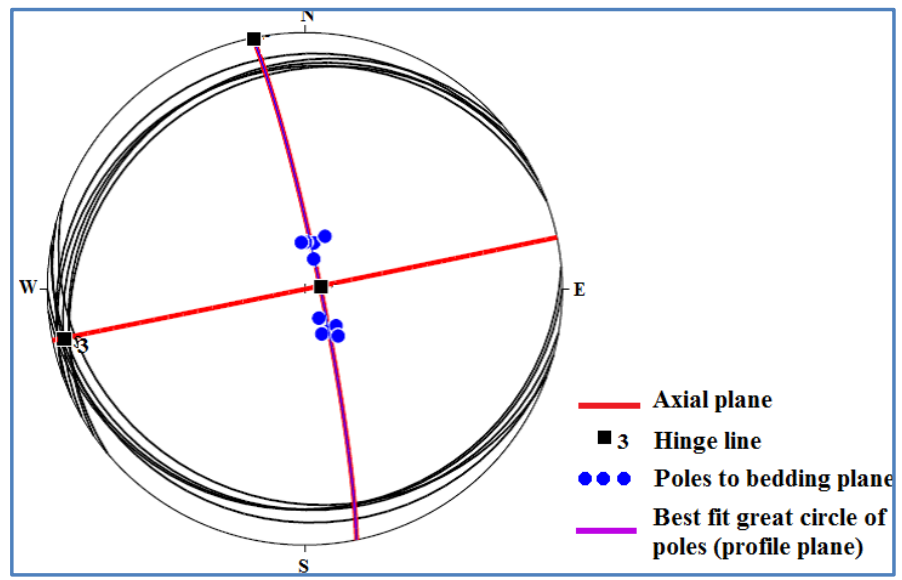

Fig. 21. Stereonet diagram shows the trend of hinge line is $05^{\circ} / 258^{\circ}$
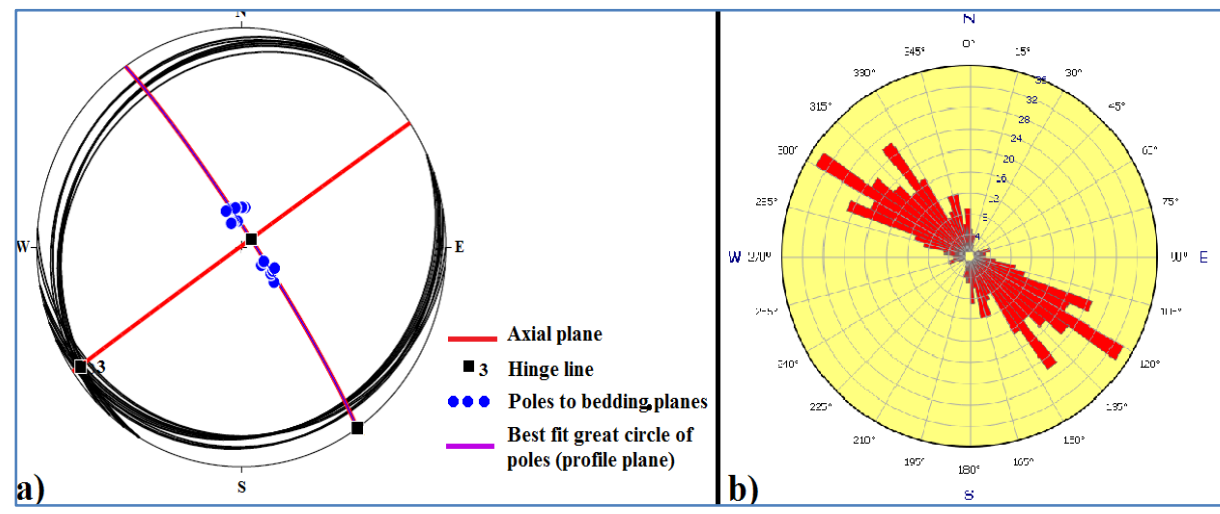

Fig. 22. a) Stereonet diagram shows the trend of hinge line is $05^{\circ} / 236^{\circ}$ b) Rose diagram of 300 joints in station 8

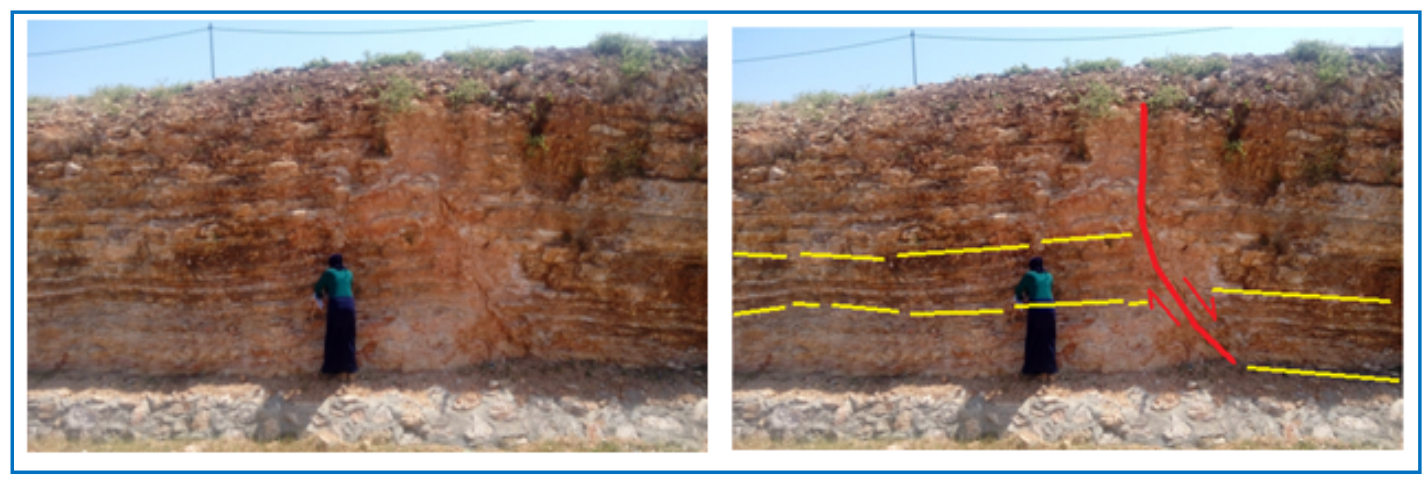

Fig. 23. Listric normal fault

\section{Station 9}

The data of this station were collected from Amman Silicified limestone and Al-Hisa Phosphorite Formation, which is about 9 km NW of Irbid city (Fig. 4). Twenty-four bedding planes were measured in the field and represented as stereographic projection and determined hinge line, axial plane and profile plane of anticline (Fig. 24a) and syncline (Fig. 24b). It shows slightly plunging symmetric anticline towards NNW $\left(07^{\circ} / 321^{\circ}\right)$. The interlimb angle 
is $160^{\circ}$ showing a gentle anticline. The syncline is also symmetric and plunging toward $\left(11^{\circ} /\right.$ $048^{\circ}$ ) with an interlimb angle of $148^{\circ}$. It also observed small highly fractured anticline at the northeastern limb of the major anticline (Fig. 25).

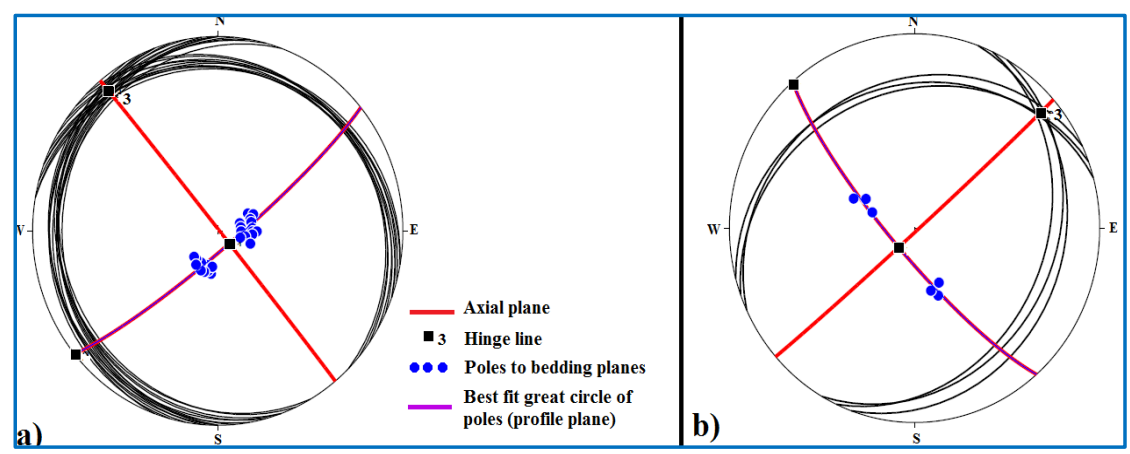

Fig. 24. Stereonet diagrams of Zahar; a) anticline, the trend of hinge line is a) $07^{\circ} / 321^{\circ}$ and b) syncline, the trend of hinge line is $11 / 048^{\circ}$

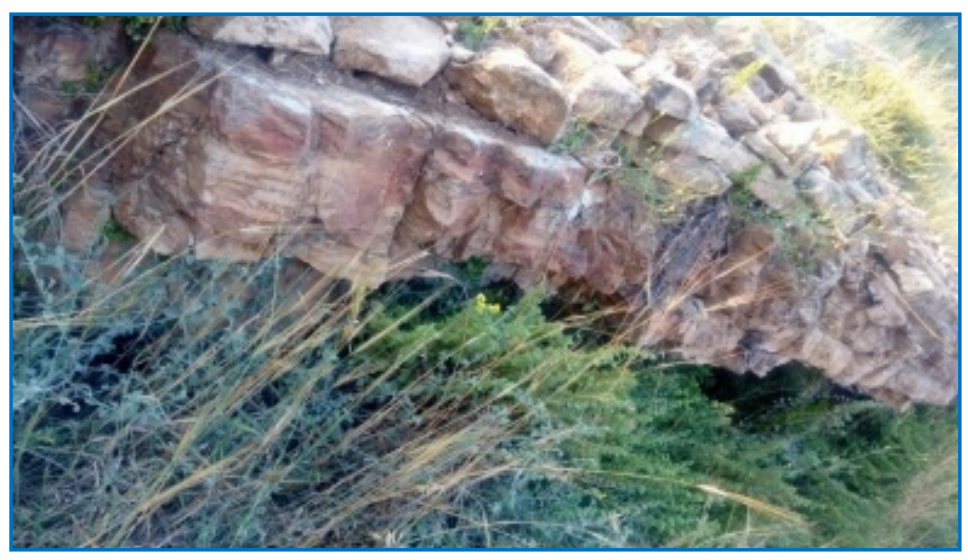

Fig. 25. Shows highly jointed limb of small anticline in station- 9

\section{LINEAMENTS}

The word "lineament" was introduced by Hobbs (1904) to characterize the spatial relationships of landscape features that included (1) crests of ridges or boundaries of elevated areas, (2) the drainage lines, (3) coast lines, and (4) boundary lines of formations, of petrographic rock types, or of lines of outcrops." (Hobbs, 1904). Any linear feature of the landscape which possesses an abnormal degree of regularity whether straight or gently curving, is generally believed to be the surface expression of some structural feature in the bedrock e.g., faults, folds,...etc. Experience and careful judgment are required to distinguish a diagnostic linear from random river stretches, hills, and similar results of random erosion (Lueder, 1959). A lineament map of the study area is produced (Fig. 26 a) and the rose diagram of the lineaments shows a major trend oriented NW- SE and two minor trends oriented N-S and NE-SW (Fig.26 b). The NW- SE trend reflects the main trend of the 
fractures in the study area, and the NE- SW trend reflects the main trend of the fold axes, whereas the $\mathrm{N}-\mathrm{S}$ trend may reflect both minor trends of the fractures and fold axes in the study area.

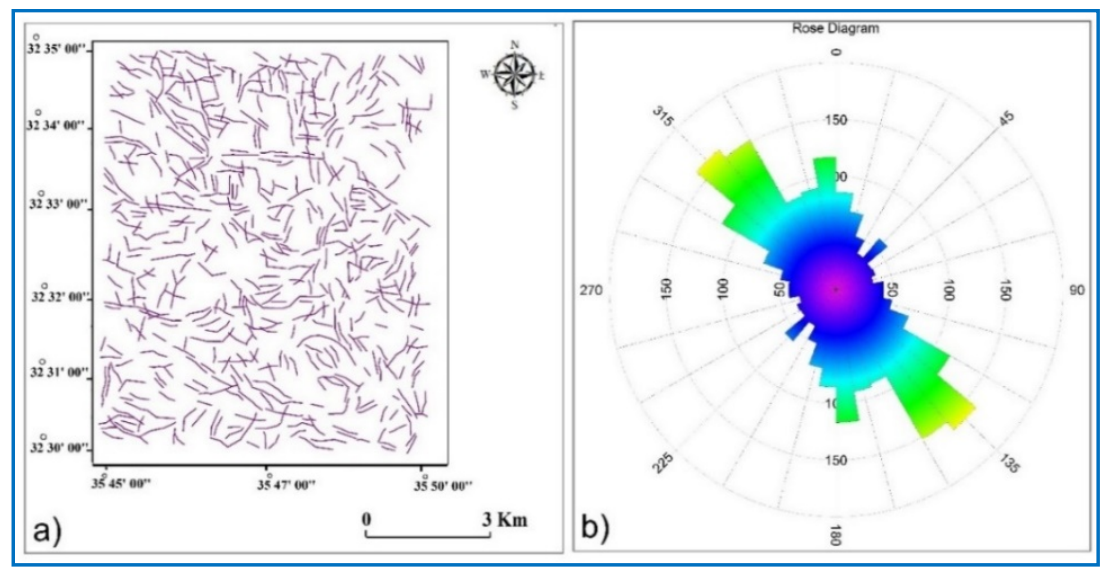

Fig. 26. a) Lineament map of the study area, b) rose diagram shows the orientation of the lineaments

\section{PALEOSTRESSES}

Indicators on fault slip planes (e.g., scratches, ridge- in grove striae, fiber crystals, mineral growth in extensional gashes, linear imprint or gouge material accumulations) are most useful tools in the reconstruction of relative displacements along the Kinematic discontinuities (Fleuty and Waever, 1975; Scholz and Engelder, 1976; Engelder and Scholz, 1976; Petit, 1987; Doblas et al., 1997; Doblas, 1998; Fry, 1999). Inversion of fault- slip data is based on the Wallace and Bott hypothesis (Wallace, 1951; Bott, 1959), which stating that fault- slip occurs parallel to the direction of the maximum shear stress.

Analysis of the fault- slip data restricted only to station- 3 of the study area in which a quarry of Wadi As Sir Formation has slickenlines. The analysis was performed using the winTENSOR program of Delvaux (2003). Results show that a dominance of strike- slip tensors which indicate three orientations; the first is characterized by $\mathrm{E}-\mathrm{W}$ compression and $\mathrm{N}-\mathrm{S}$ extension (Fig. 27), the second is characterized by NW- SE compression and NE- SW extension (Fig. 28), and the third tensor is characterized by NNW-SSE compression and ENE- WSW extension (Fig. 27). The tensors characterized by NNW-SSE to NW- SE compression and ENE- WSW to NE- SW extension are compatible with the established regional Dead Sea Stress pattern in the region (Eyal and Reches, 1983; Eyal, 1996;Diabat et al., 2004). The tensor characterized by $\mathrm{E}-\mathrm{W}$ compression and $\mathrm{N}-\mathrm{S}$ extension is compatible with the Syrian Arc stress field. Stress axes orientation of fault- slip measurements in station3 (Fig. 29) shows compression $\sigma 1$ (SHmax) and tension $\sigma 3$ (Shmin). 


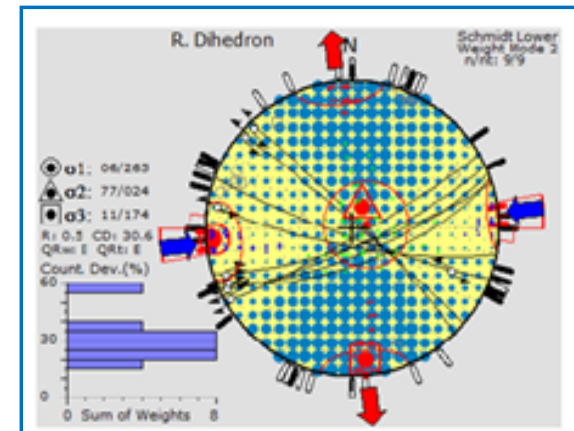

a)

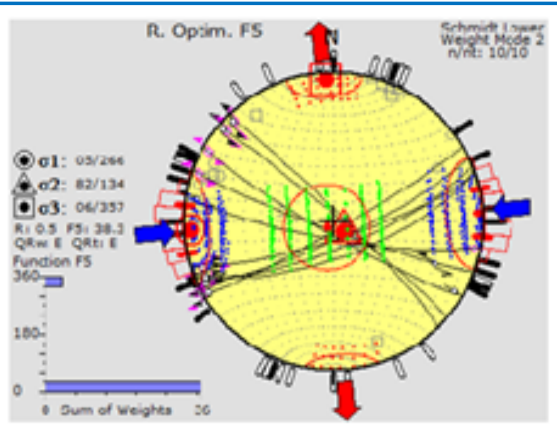

b)

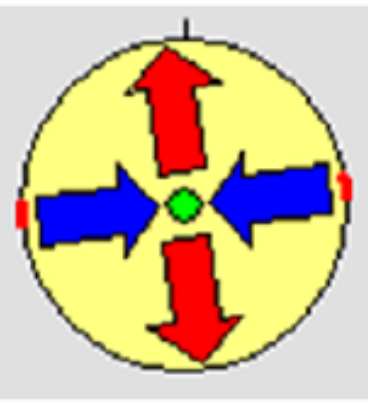

c)

Fig. 27. Stress tensor related SAS shows E-W compression and N-S extension.

Stereogram (Schmidt net, lower hemisphere) with traces of fault planes, observed slip lines and slip senses. Inward arrows indicate compression, outward arrows indicate tension, circle is $\sigma 1$, triangle is $\sigma 2$ and the square is $\sigma 3$ orientation.

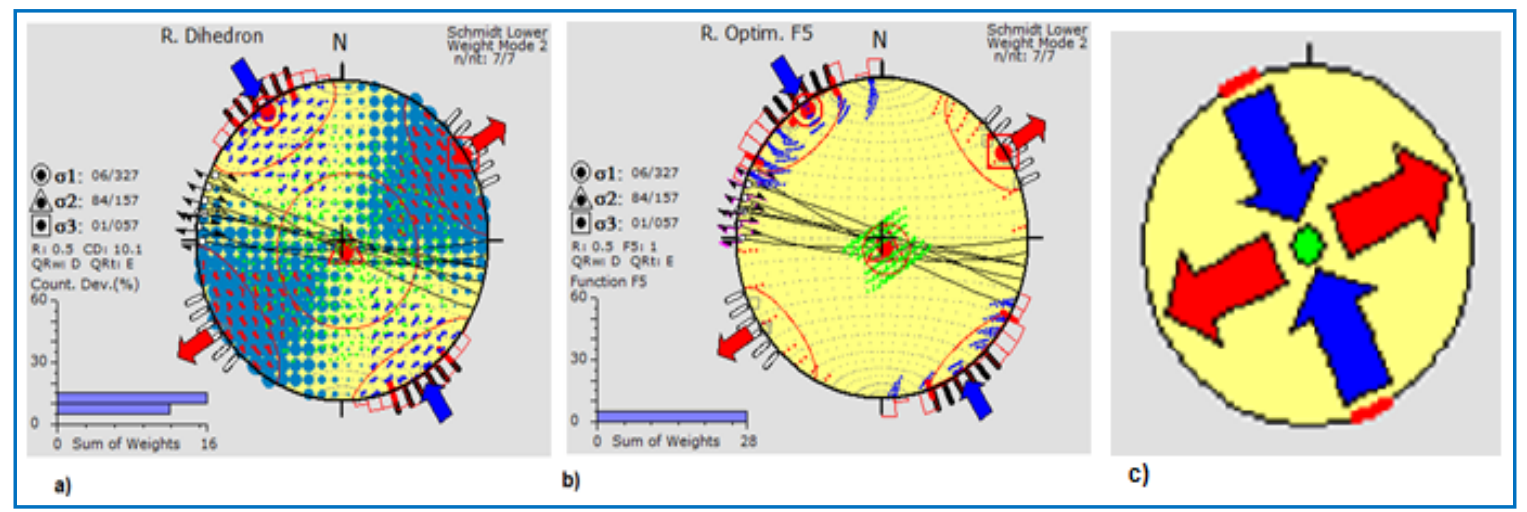

Fig. 28. Stress tensor related DSS shows NNW-SSE compression and ENE-WSW

extension; stereogram (Schmidt net, lower hemisphere) with traces of fault planes, observed slip lines and slip senses. Inward arrows indicate compression, outward arrows indicate tension, circle is $\sigma 1$, triangle is $\sigma 2$ and the square is $\sigma 3$ orientation

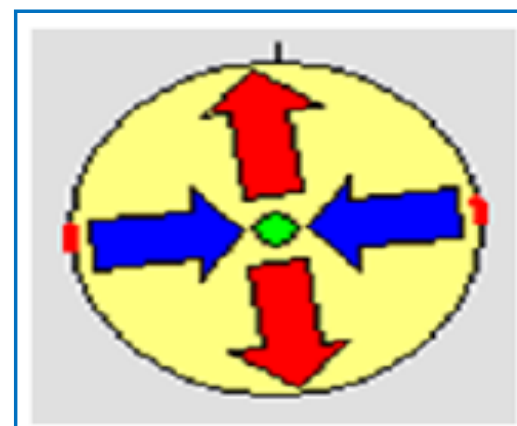

a)

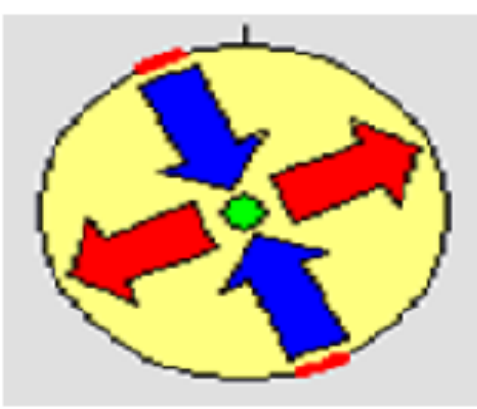

b)

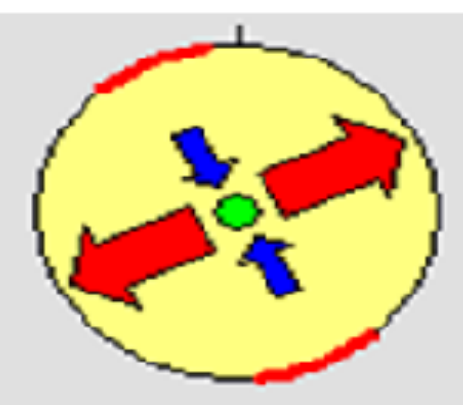

c)

Fig. 29. Stress axes orientation of fault- slip measurements in station-3; Inward arrows indicate compression $\sigma 1$ (SHmax) and outward arrows indicate tensiono3(Shmin); a) strike-slip regime related SAS, b) strike-slip regime related DSS, c) extensional regime related DSS

\section{DISCUSSION}

The study area is located at the western parts of Irbid City. The formations that outcrop in the study area are of Late Cretaceous (Turonia-Maastrichtian). The data were collected from nine 
measurement stations of the study area. The structures in the study area include; folds, faults (e.g., strike- slip, normal and thrust), and joints.

\section{Minor Folds}

Folds which are mainly anticlines in the study area characterized by gently dipping strata $\left(5^{\circ}-\right.$ $20^{\circ}$ ) and gently plunging hinge lines (fold axes) (3-18). The interlimb angles of these folds lie in the range between $120^{\circ}$ to $180^{\circ}$. This implies that they are classified as gentle folds $\left(136^{\circ}\right.$ $165^{\circ}$ ), and this means there were no highly intensive compressional stresses during their formation. Hinge lines of minor folds are mainly plunging toward SW and WSW, some folds are plunging either toward NNW, SSE, NNE, NE and SSW. The difference in the plunging direction and orientation of the hinge lines is due to the differences in the stress fields and/ or to local variations in the stresses belong either to the same stress field. To interpret the results reasonably, a direction model is produced to show the relation of our results with the main stress fields in the region e.g., the DSS field and the SAS (Fig.30). According to figure (30); the folds in stations $(3,5,7,8$, and 9$)$ are related to the DSS field, whereas folds in stations (2 and 4) are related to SAS field. Those folds in stations (1 and 6) are affected by local stresses or by block rotation.

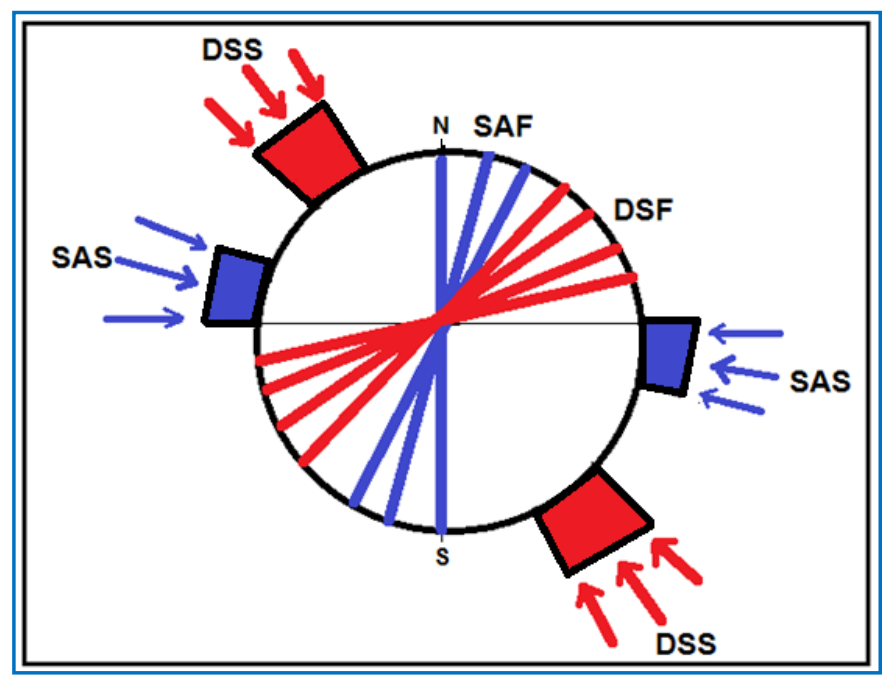

Fig. 30. A model to show the main stress fields in the region e.g., the Dead Sea stress field (DSS) and the Syrian Arc stress field (SAS), and the related folds; DSF related to the DSS field and SAF related to SAS field

\section{Fractures}

About 2800 fractures (small faults and joints) were measured in different stations of the study area along road cuts and quarries and represented as rose diagram (Fig. 31). The fractures show a major NW-SE trend in addition to minor trends in NNW- SSE, WNW- ESE and NESW. 


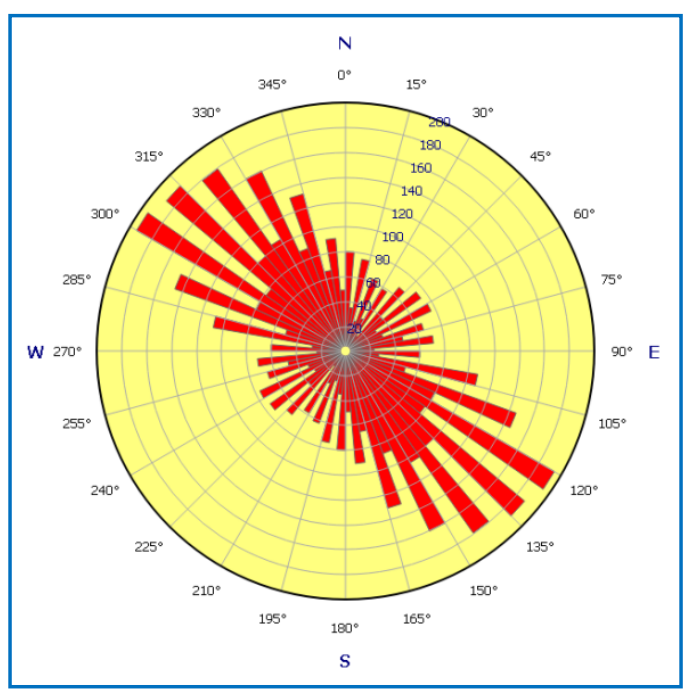

Fig. 31. Rose diagram represents strikes of all measured fractures in the study area, showing a main trend swinging about NW-SE

To interpret the results, rose diagrams represent the strike measurements in each station were displayed on the geological map (Fig. 32). It is observed that the main trend of the fractures is NW- SE (e.g., S1, S3, S5, and S8), whereas the main trend is NNW- SSE (e.g., S4) and N- S (e.g., S6), may be an indicator to a clockwise rotation in stations (S4) and (S6).

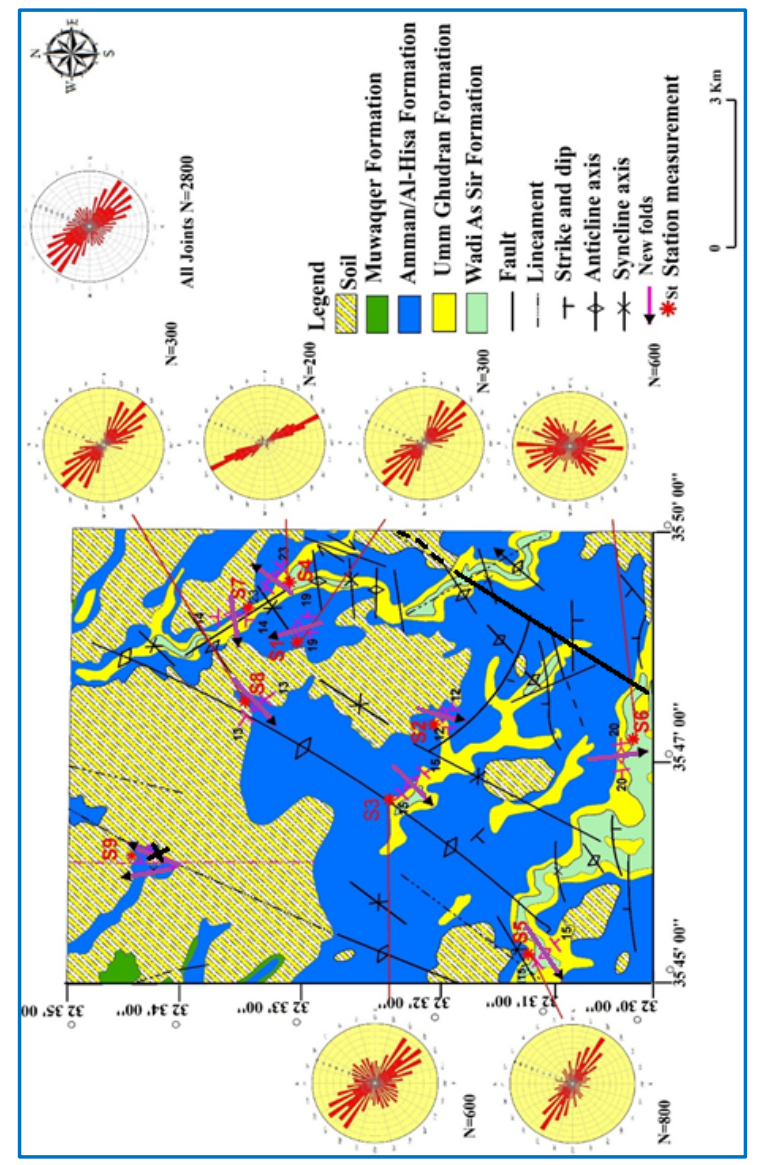

Fig. 32. Rose diagrams of the strike measurements in each station displayed on the geological map 
The attitude of all measured faults in the study area were represented as rose diagram (Fig. 33a) and stereoplot (Fig. 33 b). The main trend of the mesoscopic scale faults is striking NW- SE (Fig. 33a) and the majority of faults have high dip angles (Fig.33 b). This trend (NW-SE) represents the extensional fractures and normal faults related to the Dead Sea stress field which is predominant in the study area. This direction is in a good accordance with the NW-SE compression direction of the Reidel shear model and the deduced one from the fault slip analysis in the study area.

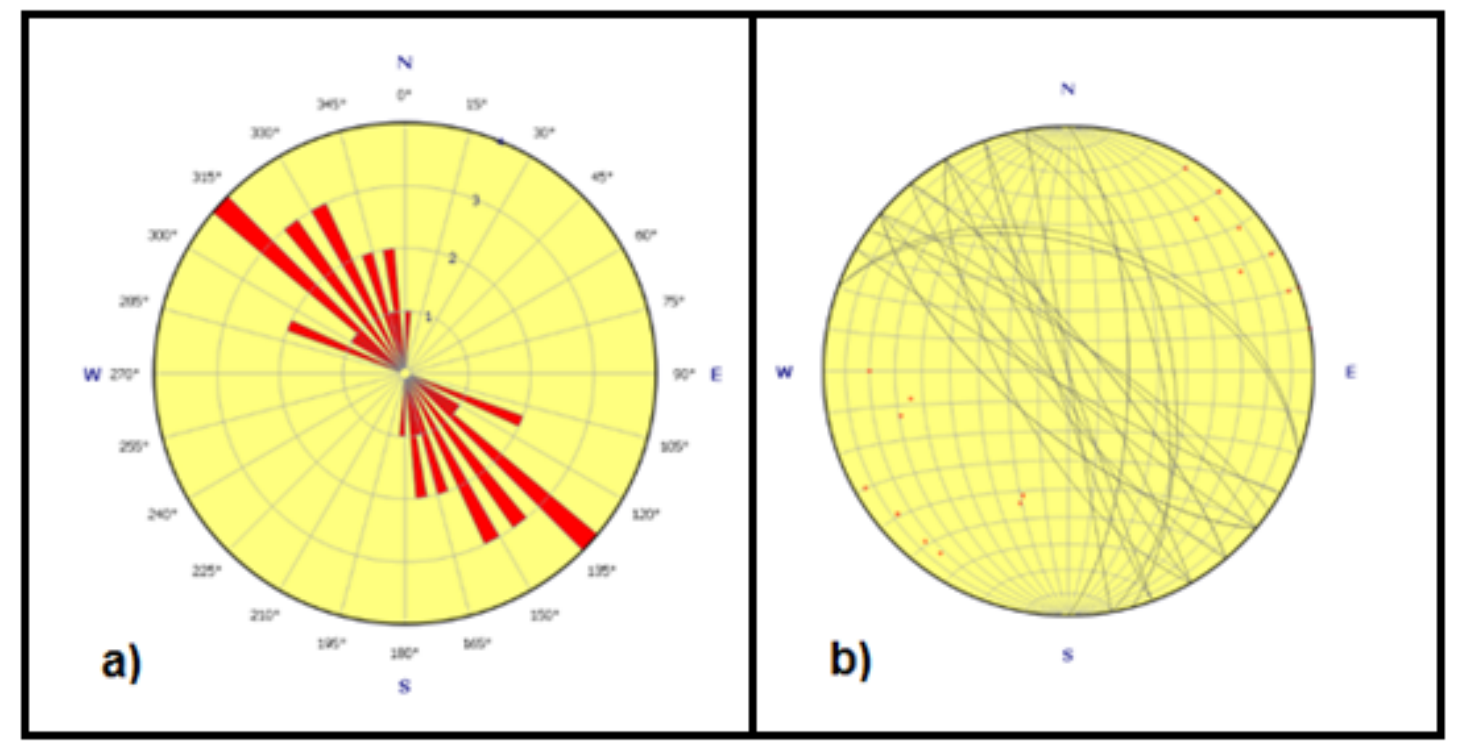

Fig. 33. a) Rose diagram represents strikes of all measured faults, and b) Stereoplot represents the attitude as great circles to show dip angles and dip directions of faults in the study area

\section{Relation of Measured Fractures with the Lineaments}

All mesofractures with 2800 measurements were represented in a rose diagram (Fig. 31) and the lineaments in (Fig. 26). From these figures it can be inferred that the main trends are generally NW-SE. This implies that the mesoscopic scale structures have the same prominent trend as main faults and lineaments in the study area. This trend generally represents the extensional fractures related to the Dead Sea stress field, as this trend is parallel to the maximum principal stress axis.

\section{Relation of Measured Fractures with the Folds and the Related Stress Fields}

Rose diagrams represent the strike measurements of fractures and stereographic projection of each fold in each station were displayed on the geological map (Fig. 34). From this figure it is concluded that the main trends of the fractures are normal to the hinge lines of the folds in stations 3, 5 and 8 and are related to the NW- SE compression of the DSS. In station- 6 the main trend of the fractures is sub parallel to the fold axis, this means that these fractures are release joints resulted during unloading when the E-W compressional stress was removed 
during the later stage of the SAS. Station-6 shows thrust fault strikes NNW-SSE, related to general E-W to ENE- WSW compression (Fig. 20) in which is related to SAS. The fold hinge line trends NNW- SSE which is related to E-W to ENE- WSW compression related to SAS, So both thrusting and folding are related to SAS. The two trend of fractures NNW and NNE may be conjugated and related to N-S compression of the DSS.

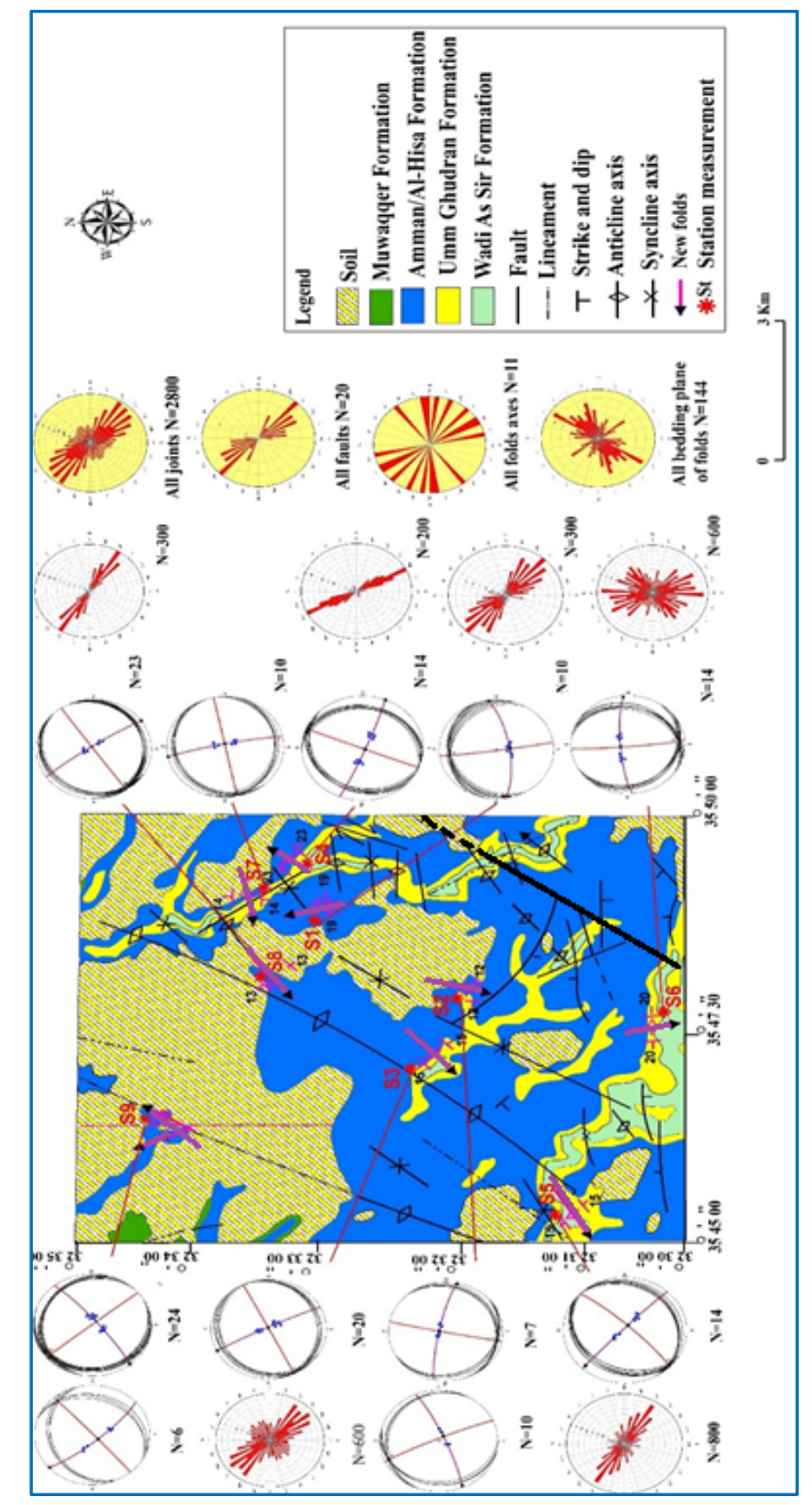

Fig. 34. Rose diagrams and stereonet measurements in each station displayed on geological map

In stations 1 and 4 the main trend of the fractures is not parallel nor perpendicular to the fold axes, which means that the fractures formed in later stages after the formation of the folds. The structural elements of the study area were displayed on the DEM (Fig. 35). From this 
figure it is concluded that the major structures e.g., folds and faults are concentrated in the southeastern half of the study area, which has the highest elevation in the area (red color). This means that the topography of the study area is structurally controlled i.e. the structures play a major role in the relief of the study area or it has morphotectonic structures.

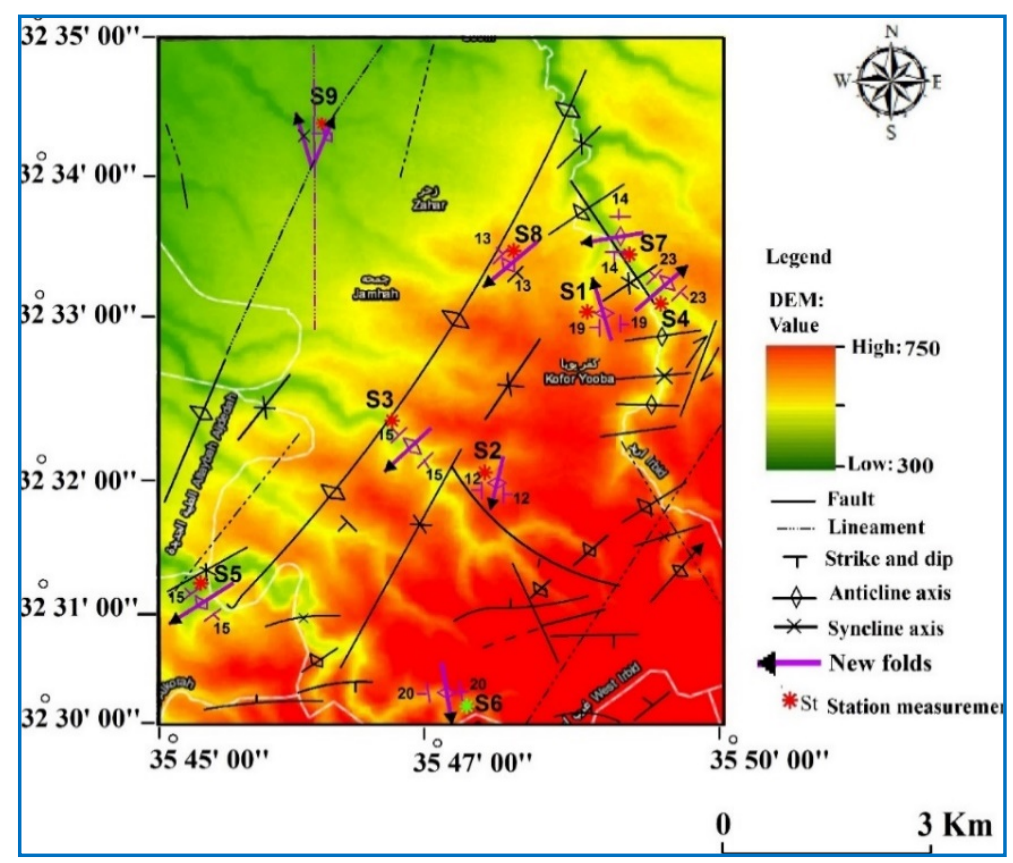

Fig. 35. A digital elevation map (DEM) with displayed structures of the study area CONCLUSIONS

1. The minorfolds in the study area are symmetric and characterized by gently dipping strata and gently plunging hinge lines (fold axes). The general plunging directions of the fold axes are toward SW and WSW. The folds in the study area are related to both stress systems SAS and DSS; Fold axes in stations (2 and 4) are trending N- S to NNE- SSW which are related to SAS field, whereas the majority of fold axes are trending NE- SW to ENE- WSW (e.g., stations 3, 5, 7, 8, and 9) which are related to the DSS field.

2. The folds have interlimb angles in the range of $\left(136^{\circ}-165^{\circ}\right)$, so they are classified as gentle folds.

3. The majority of fold axes are trending NE- SW to ENE- WSW (e.g., stations 3, 5, 7, 8, and 9syncline) which are related to the DSS field.

4. Fold axes in stations $(2,4$ and 6) are trending N- S to NNE- SSW which are related to SAS field.

5. The fold axes which are trending NNW- SSE (e.g., S9 anticline) may be due to block rotation or to local stress variations. 
6. The major trend of the measured 2800 fractures is NW-SE, whereas minor trends are NNW-SSE, WNW-ESE, NE-SW.

7. The main trend of mesoscale normal faults is striking NW-SE, that is related to the Dead Sea stress field, in which it is parallel to NW-SE compression direction.

8. The main trend of the lineaments in the study area is NW-SE which has the same trend of the measured fractures, this trend represents the extensional fractures (joints and normal faults) related to the Dead Sea Stress field, as this trend is parallel to the maximum compressive principal stress axis.

9. Some stations show the main trend of the fractures are normal to the hinge lines of the folds, whereas it is sub parallel in other stations. This means that the former are extensional and the later are release fractures.

10. The topography of the study area is structurally controlled i.e. the structures play a major role in the relief of the study area or it has morphotectonic structures.

\section{REFERENCES}

Abed, A. M., 2000. Geology of Jordan, and its Environment and Water (In Arabic), Jordanian Geologists Association, Amman, Jordan. 570pp.

Abu-Taimeh, I., 1988. Structural and Applied Remote Sensing Studies Gharandal-Petra eastern Wadi Araba. Unpublished M. Sc. Thesis, University of Jordan, Amman, Jordan.

Angelier, J., 1979. Determination of the mean principal stresses for a given fault population. Tectonophysics, 56: 17-26.

Angelier, J., 1989. From orientation to magnitudes in paleostresses determination using fault slip data. J. Struct. Geol., 11:37-50.

Atallah, M., 1992. On the Structural pattern of the Dead Sea Transform and its related structures in Jordan. Abhath Al-Yarmouk (Pure Sciences and Engineering), 1: 127-143.

Atallah, M., and Mikbel, Sh., 1992. Structural analysis of the folds between Wadi El Yabis and the Basalt plateau, northern Jordan. Dirasat, 19 (3): 43- 58.

Bender, F., 1974. Geology of Jordan. Brontrager, Berline. 196pp.

Bott, M. H. P., 1959. The mechanism of oblique slip faulting. Geological Magazine, 96:109-117.

De Ruiter, R. S. C., Lovelock, P. E. R., and Nabulsi, N., 1994. The Euphrates graben, Eastern Syria: a new petroleum province in the Northern Middle East. In: M. Al-Husseini(ed.), Geo 94, Middle East Petroleum Geosciences. Gulf Petrolink, 1:357-368.

DELVAUX, D. 1993a. The TENSOR program for paleos- tress reconstruction: examples from the east African and the Baikal rift zones. In: Terra Abstracts. Abstract supplement No. 1 to Terra Nova, 5: 216.

Delvaux, D., Moeys, R., Stapel, G., Melnikov, A., and Ermikov, V., 1995. Paleostress reconstruction and geodynamics of the Baikal region, central Asia, Part I. Paleozoic and Mesozoic pre-rift evolution. Tectonophysics, 252:61-101.

Delvaux, D., Sperner, B., 2003. Stress tensor inversion from fault kinematic indicators and focal mechanism data: the TENSOR program. Geological Society of London, Special Publications, 212: 75- 100.

Diabat, A., 2015. Structural and stress analysis of the area between Al-Akeider and Mughayer As-Sirhan, Northwestern Badia-Jordan. Jordan Journal of Earth and Enviromental Sciences, 7(1): 37-48.

Diabat, A. A., Atallah, M., and Salih, M. R., 2004. Paleostress analysis of the Cretaceous rocks in the eastern margin of the Dead Sea transform, Journal of African Earth Sciences, Jordan., 38(5): 449-460.

Diabat, A., Ahmad, F., Hammouri, N., and Obeidat, M., 2015. Karst development related to extensional fracture network at Bany-Kanana area, northern Jordan. Arabian Journal of Geosciences, 8(7): 4999-5014.

Diabat, A., and Masri, A., 2005. Orientation of the principal stresses along Zarqa- Ma'in Fault. Mu'ta Lil-Buhuth wad-Dirasat, 20: 57-71. 
Doblas, M., 1998. Slickenside kinematic indicators. The tectonic physics, 295:187-197.

Doblas, M., Mahecha, V., Hoyos, M., and lopoz- Ruiz, j., 1997. Slickenside and fault surface kinematic indicators on active normal faults of the Alpine Betic Cordilleras, Granda, Southern Spain. Joumal of Structural Geology, 19:159-170.

Engelder, J. T., and Scholz, C. H., 1967. The role of asperity indentation and ploughing in rock friction, 2 : Influence of relative hardness and normal load. International journal of Rock Mechanics and mining Sciences, 13:155-163.

Eyal, Y., 1996. Stress fluctuations along the Dead Sea rift since the Middle Miocene. Tectonics, 15: 157-170.

Eyal, Y. and Reches, Z. 1983. Tectonic analysis of the Dead Sea rift region since the Late Cretaceous based on mesostructures. Tectonic. 2: 167-185.

Fleuty, M. J., and Weaver, J. D, 1975. Slickensides and Slickenlines. Geological Magazine, 112:319-322.

Freund, R., Garfunkel, Z., Zak, I., Goldberg, M., Weissbrod, T., Derin, B., 1970. The shear along the Dead Sea rift. Philosophical Transaction of the Royal Society of London, 267:107- 130.

Fry, N., 1999. Striated faults: visual appreciation on their constraint on possible paleostress tensors. Journl of structural Geology, 21:7-21.

Garfunkel, Z., and Derin, B., 1984. Permian-early Mesozoic tectonism and continental marginformation in Israel and its implications for the history of the Eastern Mediterranean.In: J.E. Dixon and A.H.F. Robertson (eds), The geological evolution of the Eastern M Mediterranean. Special publications, Geological Society of London, 17: 187-201.

Garfunkel, Z., 1981. Internal structure of the Dead Sea leaky transform (rift) in relation to plate kinematics. In: Freund R. and Garfunkel Z. (Ed), The Dead Sea rift. Tectonophysics, 80: 81-108.

Hobbs, W.H., 1904. Lineaments of the Atlantic border region: Geol. Soc. America Bull., 15: 483-506.

Horowitz, A., 2001. Structural history. In The Jordan Rift Valley (pp. 432-477). CRC Press.

Lueder, D. R., 1959. Aerial photographic interpretation: New York, McGraw-Hill Book Co., 462 pp.

Mikbel, Sh., and Zacher, W., 1981. The Wadi Shueib Structure in Jordan.N.Jb.Geol. Palaont. Mn. H., 9 :571576.

Mikbel, Sh., and Zacher, W., 1986. Fold structures in northern Jordan. N. Jb. Geol. Palaont. Mh.H., 4: 248-256.

Moh'd, B. K., 2000. The geology of Irbid and Ash Shuna Ash Shamaliyya (Waqqass). Map sheet No. 3154-II and 3155- III.Bulletin 46, Geological mapping division, natural resources authority, Jordan.

Petit, J.P., 1987. Criteria for the sense of movement on fault surfaces in brittle rocks. Journal of Structural Geology, 9: 597-08.

Powell, J. H., 1989. Stratigraphy and sedimentation of the Phanerozoic rocks in central and south Jordan. Part B Kurnub, Ajlun and Belqa Groups. Bul.11, NRA, Geol. Directorate, Amman, Jordan.

Quennell, A. M., 1958. The structure and evolution of the Dead Sea Rift. Quaternary Journal of the Geolgical Society, 64:1-24.

Ricou, L. E., 1995. The plate tectonic history of the past Teyhys Ocean. In: A. E. M. Nairn; L. E. Ricou, B. Vrielynck and J. Dercourt (eds), The ocean basins and margins. v. 8: The Tethys Ocean. Plenum Press, New York, London, p. 3-70.

Robertson, A. H. F., Dixon, J. E., Brown, S., Collins, A., Morris, A., Pickett, S. I., and Ustamer, T., 1996. Alternative tectonic models for the Late Palaeozoic -Early Tertiary development of Tethys in the Eastern Mediterranean region. In: A. Morris and D.H. Tarling (eds), Palaeomagnetism and Tectonics of the Mediterranean region. Special Publications, Geological Society of London, 105: 239-263.

Sahawneh, J., and Atallah, M. M., 2002. Tectonic evolution of the north-eastern corner of the Dead Sea, Jordan. Abhath Al-Yarmoyk, 11: 581-598.

Scholz, C. H., and Engelder, J. T., 1976. The role of asperity indentation and ploughing in rock friction,1: Asperity creep and stickslip. International journal of Rock Mechanics and mining sciences, B: 149-154.

Sperner, B., Moller, B., Heidbach, O., Delvaux, D. R. and Fuchs, K., 2003. Tectonic stress in the Earth's crust: advances in the World Stress Map project. In: NIEUWLAND, D. A. (ed.) New Insights into structural interpretation and modelling. Geological Society, London, Special Publications, 212: 101-116.

Van der Pluijm, B. A., and Marshak, S., 2004. Earth structure, an introduction to structural geology and tectonics. $2^{\text {nd }}$ ed., W.W. Norton and Company, Inc. 656 pp.

Wallace, R. E., 1951. Geometry of shearing stress and relation to faulting. Journal of Geology, 59: 118-130.

Zain El deen, U., Delvaux, D., and Jacobs, P., 2002. Tectonic evolution in the Wadi Araba Segment of the Dead Sea Rift, South-West Jordan. EGU Stephan Mueller Special Publication Seriies,2: 63-81. 